\title{
First Spanish contribution to the Geosites Project: list of the geological frameworks established by consensus
}

Instituto Geológico y Minero de España. Ríos Rosas 23, 28003 Madrid, Spain; E-mail: garcia.cortes@igme.es

\begin{abstract}
The Geosites Project, initiated by the IUGS Global Geosites Working Group and supported by UNESCO, aims to produce a global inventory of the Earth's geological heritage. This global inventory requires a systematic methodology, based on the selection of geological frameworks of international significance in each country. These frameworks are topic events, temporal or regional geotectonic elements, etc. The second step of this methodology is the selection of the most valuable and representative sites of these geological frameworks (geosites). Fortunately, the geological diversity of Spain provides a great number of frameworks of global significance. In addition, the high quality of the outcrops (for topographic and climatic reasons) will allow for the selection of illustrative geosites. This paper presents a list of Spanish geological frameworks drawn up by consensus. It was prepared in accordance with the Geosites Project methodology, without taking into account the National Inventory of Geosites, which is in progress and covers $40 \%$ of Spanish territory. The IGME (Geological Survey of Spain) drew up a preliminary list, which was sent to all the university departments of geology, mining schools and research centres, for analysis, discussion and improvement. The result of this request was the selection of 20 frameworks, forming the first Spanish contribution to the Geosites Project.
\end{abstract}

\section{Introduction}

Conservation of the geological heritage at the world level requires, like all such conservation exercises, a rigorous preliminary inventory. In this case, the inventory can, and should, be drawn up only by the international geoscientific community. On behalf of this community, the IUGS has for some years been promoting an ambitious global initiative in the field of geoconservation: the Geosites Project (Wimbledon, 1996). The objective of this initiative, which is also sponsored by UNESCO, is to draw up an evolving and comprehensive computer-based inventory, to spread geological knowledge among the public and to serve as a basis for subsequent geoconservations, such as the declaration of areas protected for their geological merits.
It is obviously difficult to select a certain number of sites of geological interest representing the geological history of the earth. One has only to consider the complexity of the geological register and the extreme diversity of events, lithologies and palaeoenvironments, not only in space but also in time. Another problem is the lack of inventories drawn up with scientific rigour in practically all countries.

The only thing working in our favour is the existence of a universal scientific language common to the entire geological community. With this instrument, Geosites Project proposes a methodology to solve the problem, centred on comparison of the interest and merits of a series of sites representative of previously defined geological frameworks. These frameworks are selected in each country on the basis of their special significance for the world geological register. In this way, the geosites are not selected in isolation but within a chosen context (Wimbledon, 1998). The concept of framework, defined as a regional geotectonic element, tectonic, metallogenic or other event, stratigraphic section, palaeobiological associations, etc., is a concept of vital importance which should not be lost sight of in the immense geological diversity at world level.

In synthesis, the methodology proposed in the Geosites Project for establishing the final list of sites of geological interest of world importance may be summarised as follows:

a) The establishment in each country of a network of thematic and regional experts covering all the necessary disciplines.

b) The selection and definition in each country of the most outstanding frameworks at international level.

c) The selection and definition, using standard formats, of geosites representative of the geological frameworks defined in the previous phase.

d) Comparison of the significance of the geosites established in different countries, and definitive selection of those warranting inclusion on the final list of sites of geological interest of world importance. This phase should be undertaken by experts from different countries, grouped in thematic and/or regional contexts.

\section{Scope and performance of the work}

Those responsible for the Geological Heritage at IGME (Spanish Geological Survey) considered it necessary to provide a list of geosites in Spain of international relevance for this world inventory. The National Inventory of Sites of Geological Interest, initiated by IGME in 1977 and in which all sites are given local, regional, national or international scope on the basis of their merits, could have been used for this purpose. The methodology used for this inventory is included in Elízaga et al. (1994).

However, for the proposed purpose, it was decided not to use the National Inventory, for two fundamental reasons. Firstly, over the more than twenty years that the inventory has been under way, 


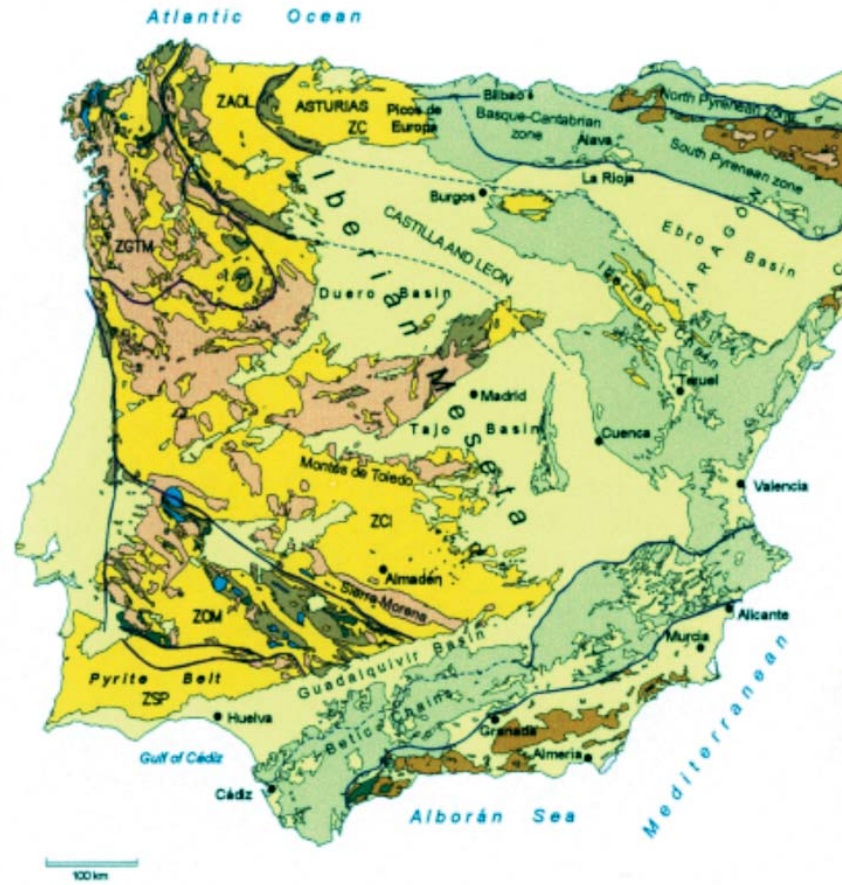

Figure 1 Simplifed geotectonic map of the lberian Peninsula and the Balearic lslands.

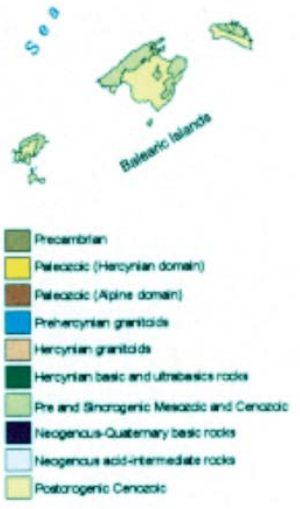

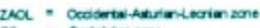

zc: Cortasion zone

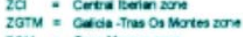

zon : Ona Mreve are

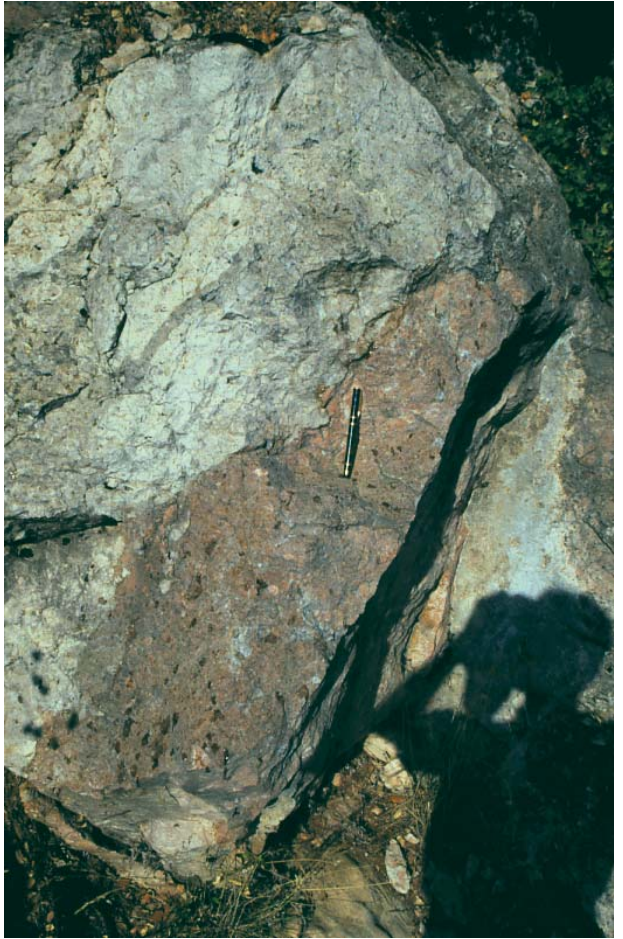

Figure 4 Neptunian dyke (Jurassic, Betic Chains).

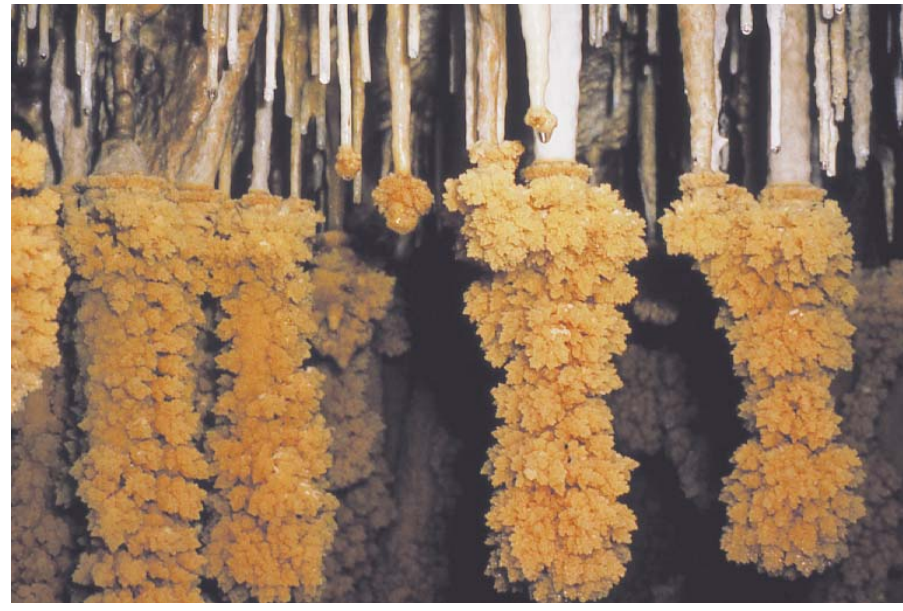

Figure 2 Epiaquatic speleothemes, Nerja cave (Málaga, South Spain).

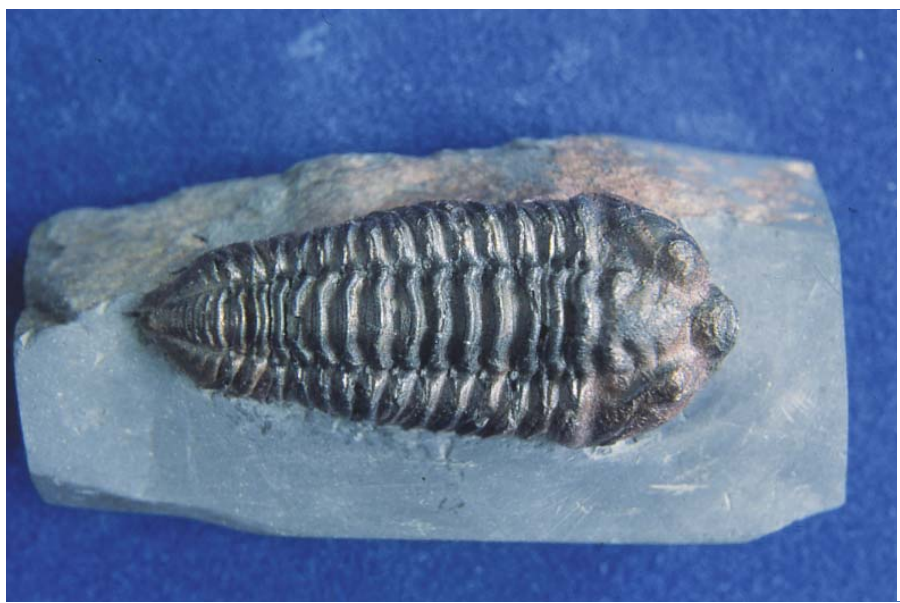

Figure 3 Neseuretus tristani (Ordovician).

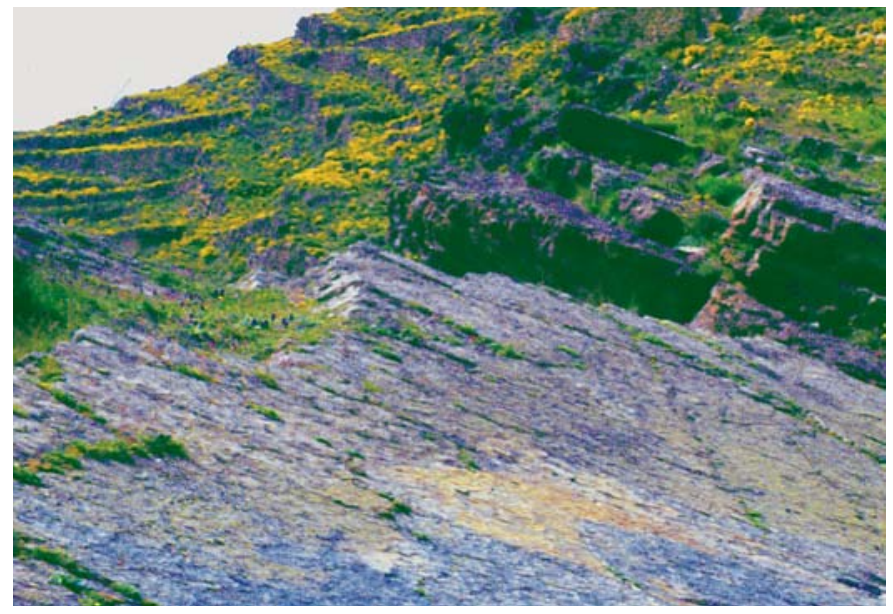

Figure 5 Dinosaur footprints (Peñaportillo, La Rioja).

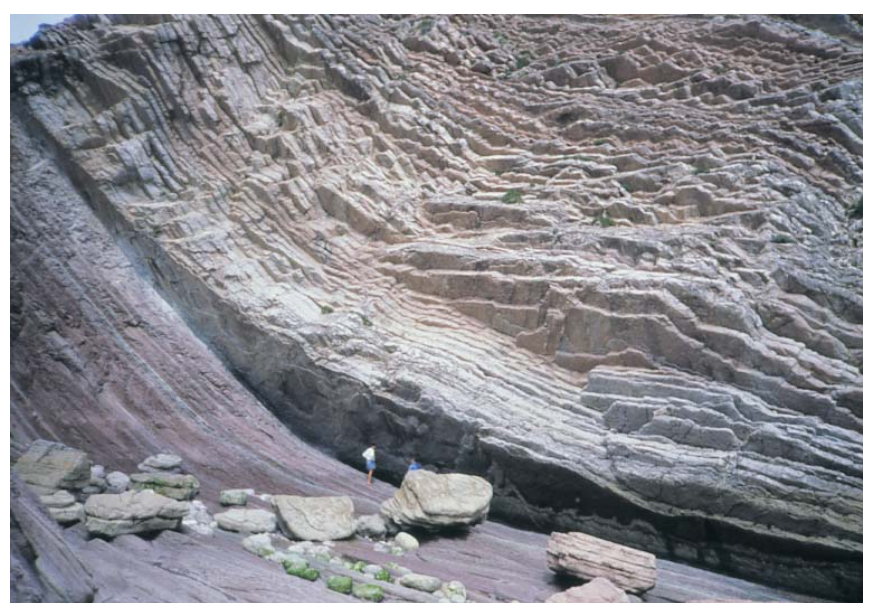

Figure 6 K/T boundary (Zumaya, Guipúzcoa, North Spain). 


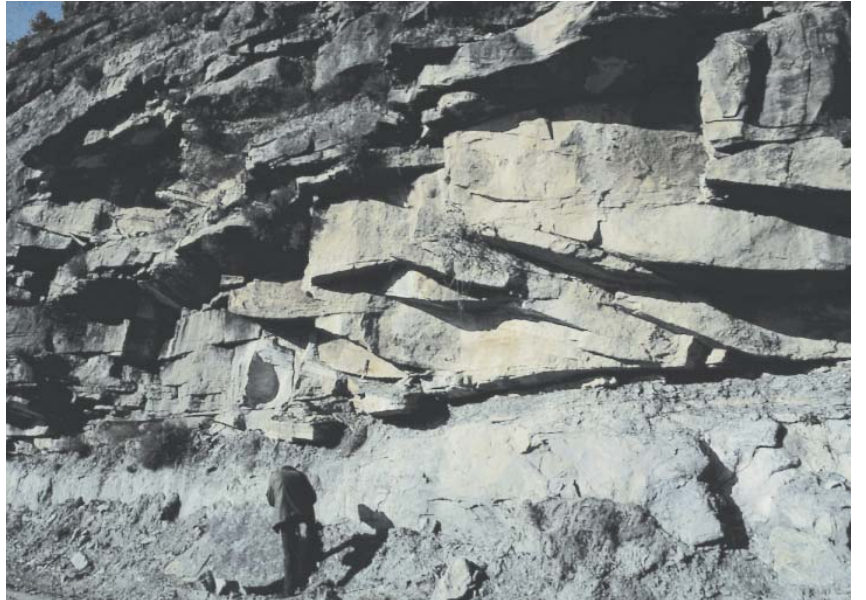

Figure 7 Tidal sigmoids (Pyrenees, NE Spain).

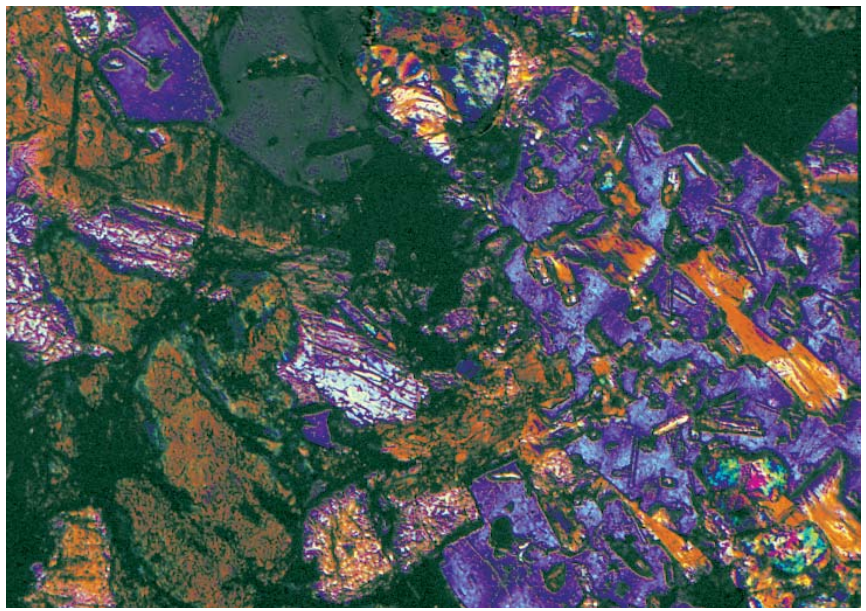

Figure 9 Cancalite (Cancarix, SE Spain).

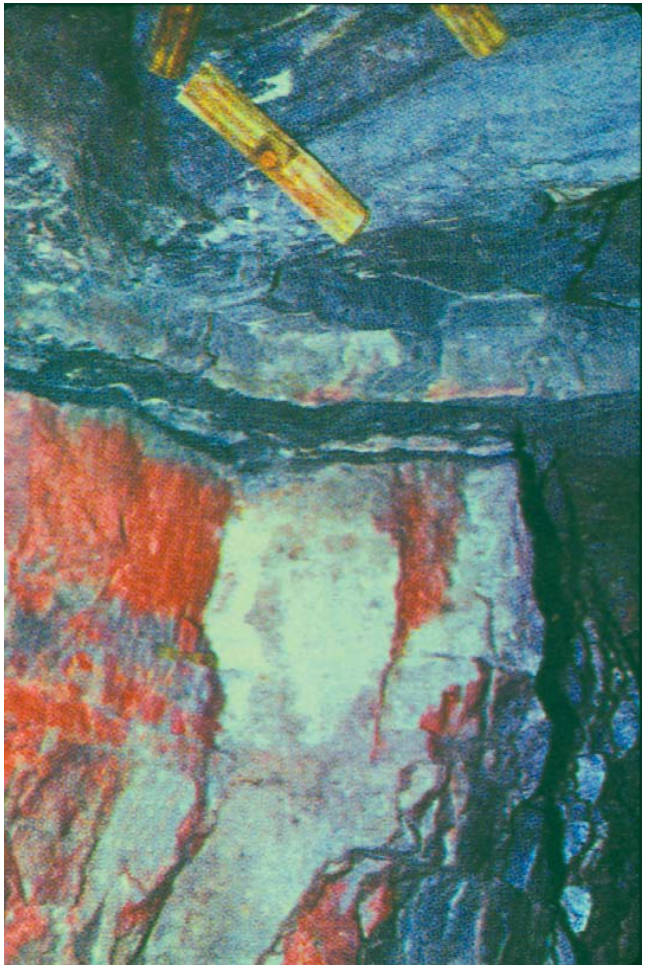

Figure 11 Cinnabar mineralization in Llandovery quartzites (Almadén, Central Spain).

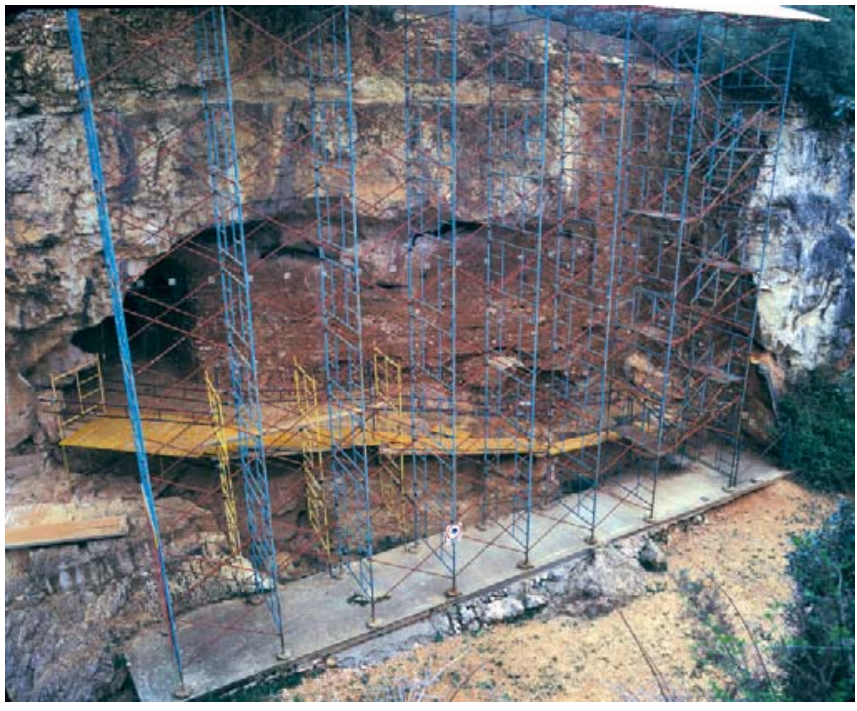

Figure 8 Atapuerca Pleistocene karstic deposits (Burgos, North Spain).

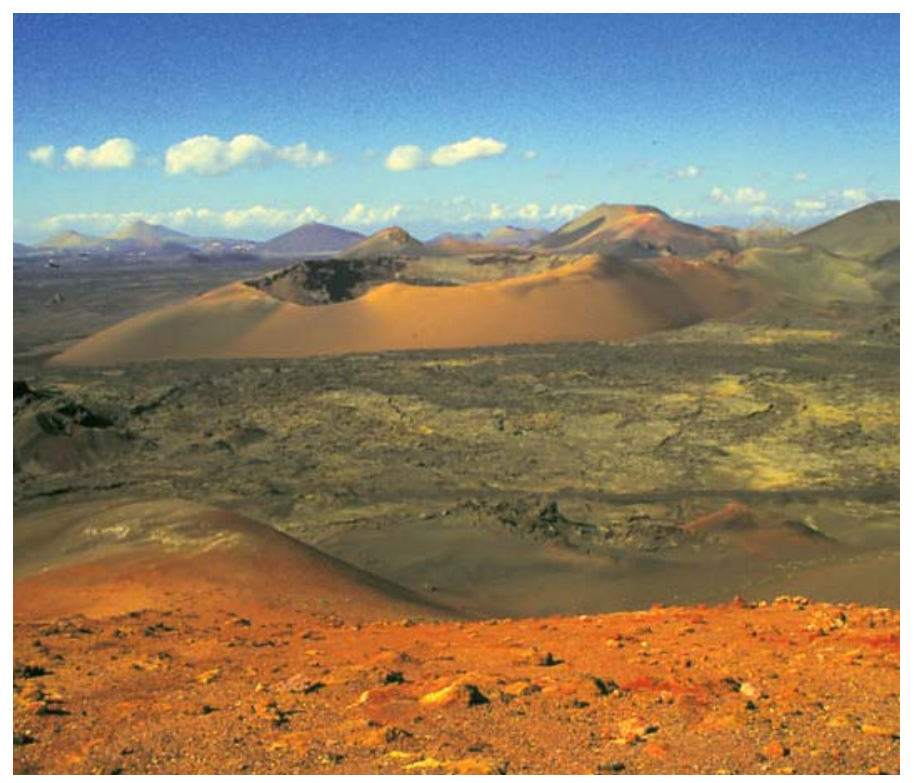

Figure 10 Timanfaya National Park, Lanzarote island (Canary lslands).

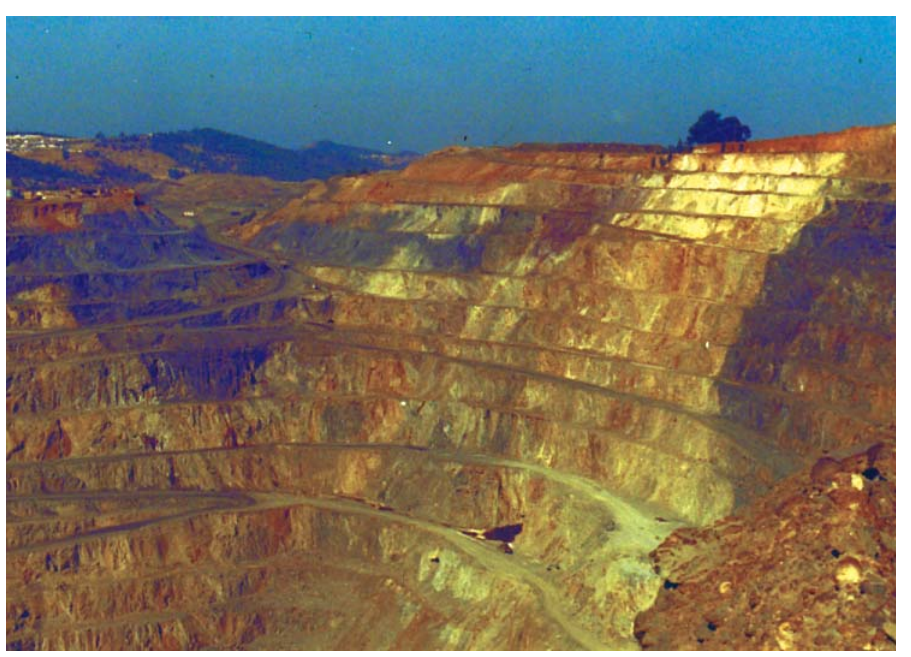

Figure 12 Río Tinto open pit (SW Spain). 
only $40 \%$ of the national territory has been covered, and it would have been unrealistic to imagine that it might be concluded in time for sites of international scope to be obtained from it. Secondly, it was considered appropriate to use a methodology shared by the largest possible number of countries, and allowing the attainment of standard and coherent final results.

The aim of this work has been to cover the first and second phases of the methodology proposed in the Geosites initiative, i.e., to establish the list of Spanish frameworks of international relevance and to define them suitably. Furthermore, this objective was to be achieved with the highest possible degree of consensus, an aspect of vital importance, which we believe has been achieved.

With this aim in mind, a multidisciplinary working group was set up at IGME, which drew up an initial list of 18 Spanish frameworks of world significance. This list was sent, by way of a survey, to all the university departments of geology, mining and land engineering, as well as to public research institutes and scientific societies related to the Earth Sciences. A total of 55 institutions were consulted. Almost a third responded with suggestions and observations, prepared by somewhat more than $6 \%$ of the professors or scientists working at these institutions.

With all these responses, which extended and/or provided new insight into the original draft-list, the IGME working group drew up the definitive list. This included 20 geological frameworks of world importance, and is the first Spanish contribution to the Geosites project (Figure 1).

The list presented below was grouped by subject areas in its original version. In the definitive version, this type of grouping of frameworks has been changed, since many are multidisciplinary in nature, a fact that undoubtedly contributes to increasing their intrinsic interest. The descriptions accompanying these contexts are necessarily no more than a summary of the nature and merits of each. They do not purport to be exhaustive, nor do they contain all the arguments explaining the reasons for their having been selected.

\section{River network, rañas and Appalachian landscapes of the Hesperic massif}

The Iberian Meseta is formed by a Hercynian massif known as the Hesperic Massif, and by various associated Cenozoic basins. The current landscape of the massif is a testimony to its alpine evolution.

The hills of the Montes de Toledo and the Sierra Morena are magnificent examples of Appalachian-type relief. Valleys alternate with narrow, flat-topped mountain chains of constant height, sketching the structures of hercynic geology. These constitute a "living" palaeorelief, since their origin is interpreted as the result of the specific Cretaceous geotectonic and climatic features that gave rise to generalized flattening and to strong processes of chemical weathering (Molina et al., 1987), and to the initial Cenozoic geotectonic destabilizations that caused physical erosion.

The origins of the current river network are as old as any other element of the relief of the Iberian Hercynian Massif, although many of the original features have disappeared (Martín-Serrano, 1991). However, the current configuration still has sufficient arguments to sustain this hypothesis of age: deep gorges, the genesis of which is imaginable only under synorogenic conditions (Bertrand, 1971); phenomena of superimposition or antecedence (Birot and Solé, 1954); and, in short, the shape of the hydrographic network, a complex web the long evolution of which has caused many phenomena of capture, giving rise to spectacular hanging landscapes, the most outstanding representative of which is the raña. The raña are pebbly uplands located always at higher elevations than those of fluvial terraces (Martín-Serrano, 1988). They are relics of perimountainous fluvial plains, conserved as they were in the remotest areas of the interior of the massif.

\section{Low coasts of the Iberian Peninsula}

The Spanish eastern Mediterranean coast and the Gulf of Cadiz on the Atlantic ocean are magnificent examples of low coasts, showing the changing effects of coastal geodynamics with great scientific interest for palaeogeographical, palaeoclimatic and palaeoenvironmental studies. Many of these sites, which are of great natural beauty and biological richness, are currently natural parks, and almost all of these coasts have been declared protected areas.

Both of these coasts conserve traces of fluctuations in sea level in the most recent geological times, and on both the distensible and subsiding geotectonic regime initiated in the Miocene still persists. There are abundant signs of old coastline positions, represented by marine terraces, coastal spits, beaches, etc, many well dated by radiometric and palaeontological methods. In certain cases, they are privileged areas because of their Tirrenian fossil registers (Goy et al., 1986).

The present coast is represented by a complex system of coastal spits, barrier-islands, lagoons, coastal pools and swamps, especially at Valencia, Cadiz and Huelva, while deltas are the most characteristic feature of the coast of Catalonia.

The development of wind-induced deposits is evidently extraordinary. Particularly outstanding is the oldest of the registers (Pliocene-Pleistocene), constituted by oolitic dune systems associated with fossil Tirrenian beaches running from Jávea (Alicante) to the Cabo de Gata (Almería) and giving rise to spits of land enclosing coastal lagoons (Zazo and Goy, 1994). The most varied and complex dune system is currently the one at Doñana, which closes off the floodplains of the Guadalquivir (Borja et al., 1999; Zazo et al., 1999).

\section{Carbonate and evaporite karstic systems of the Iberian Peninsula and the Balearic islands}

Almost $20 \%$ of Spanish territory is made up of outcrops of karstified materials. The numerous karstic systems, present, current or past, are of great interest and extraordinary diversity.

From a geomorphological point of view, the karstic landscapes shaped in the Paleozoic limestones of the Picos de Europa, the Pyrenees and the internal areas of the Betic Chain are spectacular, and include certain unique nivo-karstic morphologies. The Mesozoic carbonated formations of the Iberian Chain, the Cantabrian coast and the Betic Chain, including their prolongation in the Balearic Islands, show a wide range of exokarstic morphologies, with polje type depressions, megalapies fields and stone cities (Ayala et al., 1986).

The endokarstic morphologies are also rich and varied. More than 10,000 karstic cavities are known in Spain, of which a significant number are highly developed longitudinally or vertically. Nine of them are more than 1,000 $\mathrm{m}$ in depth, and the most highly developed horizontal underground network reaches $100 \mathrm{~km}$ (the Ojo Guareña complex in Burgos). In some of these cavities, the presence of numerous speleothemes has made it possible to carry out geochronological, isotopic and palaeo-environmental studies (Durán, 1996) of great interest regarding the climatic evolution of the Quaternary in the western Mediterranean (Figure 2).

From a hydrogeological point of view, the aquifers that constitute these karstic systems are also of great scientific and applied interest. There are also noteworthy examples of unique karstic springs, many of them linked to the birth of certain important peninsular rivers.

Finally, the great scientific importance of the palaeontological and archaeological register of the Spanish endokarst cannot be ignored. 
The Mesozoic (fundamentally Triassic) and Cenozoic evaporitic formations have also developed karstic systems of a high degree of relevance at world level. An example is the karst at Sorbas in the southeast of the Peninsula. In just $16 \mathrm{~km}^{2}$ of Messinian gypsum outcrops, more than 600 cavities are concentrated, many of them measuring more than $6 \mathrm{~km}$ (Calaforra, 1996). The presence of exokarstic and endokarstic morphologies and the interest of hydrogeological behavioural studies of the gypsums make this protected area an exceptional site at world level.

Furthermore, the phenomena of subsidence caused in the alluvial deposits of certain Cenozoic basins (fundamentally the Ebro and Tajo), due to the underlying karstification of evaporitic formations, are of great interest (Gutiérrez, 1996). They are unique examples of synsedimentary and postsedimentary palaeosubsidence, as well as current geological analogues of active karstic subsidence, with major socio-economic implications because they pose the risk to infrastructues.

\section{Lower and Middle Paleozoic stratigraphic series of the Hesperic massif}

The Hesperic massif contains the most extensive and fossil-bearing outcrops of all those formations making up the European Hercynian Chain. Its different structural and palaeogeographic areas include important stratigraphic sections from the Cambrian and Devonian periods.

The Cambrian materials show exceptional successions in the Cantabrian and Ossa-Morena areas, as well as in the Iberian Chain. The calcareous and terrigenous formations have served to typify a series of chrono-registering units from exceptionally complete fossil-bearing stratigraphic sections, which have demonstrated an enormous potential for correlation with northern Africa, Newfoundland and Southern Europe. The regional Mediterranean scale thus formed includes the Cordubian, Ovetian, Marianian and Bilbilian divisions (Lower Cambrian), as well as the Leonian and Cesaraugustian (Middle Cambrian), all containing Spanish stratotypes (Liñán et al., 1993).

The Ordovician materials of the Hesperic Massif are a compendium of sedimentary facies, widely developed at the edge of the palaeocontinent of Gondwana (Armorican Quartzite, Tristani Beds, Pelites à fragments) in relation to global transgressions and regressions and to late Ordovician glaciation. The fossil record is greatly conditioned by the shallow facies of the platforms, and has served, among others, to characterise the Oretanian division of the regional Mediterranean scale (Gutiérrez-Marco et al., 1995) (Figure 3).

The Silurian successions are especially continuous and fossilbearing in the Ossa Morena Zone, and are linked to the more distal environments of the perigondwanic platforms, where facies of graptolitic black slates with certain calcareous intercalations are developed. Some of them are of universal relevance (Rábano et al., 1999), and contain numerous physical and biological events in the Silurian to be studied. In the rest of the Hesperic Massif shallower deposits prevail; nevertheless, the presence of graptolitic black slates at the base of many of these successions provides relevant sections (Gutiérrez-Marco et al., 1998), which are now being used at world level as references in high-resolution biochronostratigraphy.

The Devonian successions of the Hesperic Massif are internationally famous, with shallow perigondwanian environments and outstanding faunal endemisms (García-Alcalde, 1996). There are also complete successions in more pelagic facies ("Hercynian magnafacies") that make it possible to correlate most of the chronostratigraphic boundaries and physical or biological events occurring at world level (García-Alcalde et al., 1990).

In addition, the Paleozoic outcrops of the Hesperic Massif are also exceptionally important from the palaeontological point of view. This is due to the palaeogeographic situation of the area at the edge of the palaeocontinent of Gondwana, which evolved from peripolar latitudes (Cambrian and Ordovician) to intermediate and palaeotropical latitudes (Silurian and Devonian), typifying environments that are almost unknown in other areas of the world. The abundant endemisms have led to the characterisation of dozens of new genera and hundreds of new species in all invertebrate groups, over a century and a half of research.

\section{The Carboniferous period in the Cantabrian Chain (NW Spain)}

One of the most relevant characteristics of the Carboniferous in the Cantabrian Chain is the great continuity of the sedimentary sequence, without significant interruptions, and the great thickness of the sediments accumulated, which reaches almost 6,000 m. Only the lower Carboniferous, in the most basal part, is poorly represented, with reduced thicknesses (not exceeding $50 \mathrm{~m}$ ), due to the presence of condensed series.

The special interest of the Carboniferous in the Cantabrian Chain is centred on the sedimentological, biostratigraphical and palaeontological aspects.

From the sedimentological point of view, the presence of complete sequences of filling of the different sedimentary trenches is particularly noteworthy, the progradation of which gave rise to the Carboniferous foreland basin. These sequences are shallowing upwards, and begin with deep marine sediments of olistostromic and/or turbiditic type, followed by terrigenous or terrigenous-carbonated shallow marine shelf sediments, culminating with fan delta deposits with abundant layers of coal.

Particularly outstanding in this respect are the deltaic sequences and fan deltas, certain olistostromic sequences with large olistolites arising during the initial filling phases of the foreland trenches (Heredia et al., 1990), and outcrops of thick carbonated series, constituting unique examples at world level. It is possible to observe the biotic communities that formed the reef ecosystems of the Carboniferous, the transition from platform to basin recorded in the stratification geometry, the evolutive models of carbonated ramp-shelf, the fabric of the sediments in carbonated slopes, inclined depending on the palaeobathymetry, etc., (Bahamonde et al., 1997). Finally, the stratigraphic relationships that may be observed between the detritic and carbonated systems of the distal edge of the foreland basin are also of interest.

Regarding biostratigraphy, the interdigitation of continental transition deposits with marine deposits makes this Carboniferous basin exceptionally useful for the establishment of correlations between western European scales, based on palaeobotanical records, and the Russian scale, based fundamentally on foraminifers (Martínez-Diaz et al., 1983; Villa, 1995).

From the point of view of palaeontology, some locations in this Carboniferous basin stand out for their palaeobotanical deposits. This is the case, for example, of the small basins of Guardo and Sabero. In the first one, the best flora of the Westphalian D and the Cantabrian have been described. While there are no materials of this age in most parts of Europe and North America, due to erosion during the Hercynian orogenic period, at Guardo there is a complete sequence in predominantly continental facies, where it is exceptionally simple to observe the flora marking the transition from the Westphalian to the Stephanian ( Wagner et al., 1983).

Regarding the Sabero Basin, its interest at world level lies in the excellent exposure of deposits with flora from the Barruelian to the Stephanian B, compared to the classical sites corresponding to the Stephanian in southern France. Particularly interesting is the presence of both humid and dry habitats, allowing both stratigraphic and palaeoecological comparative studies to be carried out (Knight, 1983). 


\section{Mesozoic Series in the Betic and Iberian chains}

During the Mesozoic, the Iberian plate was situated in a distensible tectonic context that allowed for the development of passive margins surrounding the Tethys to the northwest. These passive margins included the Betic mountain chains and the Iberian Chain. During their geological evolution, the Trias and lower Lias show an initial stage with continental and marine deposits, culminating with the development of a particularly extensive shallow carbonate shelf. As for the Middle Lias, this great platform is fragmented as a result of initiation of a stage of rifting, such that trenches and thresholds conditioning sedimentation are formed. This generated very varied environments that lasted until the beginning of the compressive stage at the end of the Cretaceous or the beginning of the Paleogene (Vera, 1988). These Mesozoic sedimentary environments are especially easy to observe in the external areas of the Betic chains and the Iberian Chain, and have been recorded in the regional stratigraphy, in which there are very well exposed series. These contain palaeontological, stratigraphical and sedimentological elements, making this region a geological context of great importance on the European continent.

Regarding the palaeontological interest of the biozones, innumerable taxons have been described in the ammonites group, their type series and horizons being found in Jurassic and Cretaceous materials.

In relation to stratigraphy, in both the Jurassic and the Cretaceous there are numerous sections that are considered for proposal or are being proposed to the international community as being limit stratotypes for numerous divisions, or are internationally recognised reference sections for certain intervals.

Finally, in this context the sedimentology is of great relevance, due to the existence of easily accessible outcrops of exceptional quality. Throughout the region there are magnificent examples of tectonic-sedimentation interaction, with palaeofaults, halokinetic structures, progressive and angular unconformities, slumps, etc. (Figure 4). There are also certain lithologies, facies or associations of facies that constitute unique examples at world level (MartínAlgarra et al., 1992; Ruiz-Ortiz et al., 1985).

\section{Fossils and ichnofossils of the continental Cretaceous on the Iberian Peninsula}

The Weald facies of the Iberian Peninsula contains certain exceptionally well-preserved deposits of fossils and ichnofossils. Favourable palaeogeographic environments with a profusion of deltas, lakes and marshes have allowed a varied range of fossil remains and traces to be accumulated and preserved.

Undoubtedly outstanding are the deposits of dinosaur ichnites, which although also found in Aragon, Asturias, Castilla y León, Catalonia and Valencia, are especially abundant in Rioja (Figure 5); in this region alone, more than 8,000 prints measuring between $8 \mathrm{~cm}$ and $87 \mathrm{~cm}$ have been located and included on the inventory. This profusion of prints has made it possible to study in detail the ecology and ethology of numerous groups of dinosaurs, both carnivorous and herbivorous, biped and quadruped, sauropods, teropods, ornithopods, etc., which date back to between 140 million and 120 million years. These ichnites have made it possible to study anatomical structures not present in deposits of fossil remains, such as interdigital membranes (Casanovas et al., 1992).

Also noteworthy are the deposits of dinosaur eggs, such as those found at Basturs (Lérida, Catalonia), thanks to which embryological and ethological studies of different dinosaur groups have become possible.
Associated with these deposits, or in others of similar age, there are both sub-aquatic and terrestrial flora and fauna. Special mention should be made of the Las Hoyas deposit (Cuenca), where, among other remains, some of the oldest birds on the world register have appeared, and magnificently been preserved in the lithographic limestones of the area.

Finally, this framework is also enriched with important deposits of amber containing perfectly fossilised insects that have appeared in the Utrillas facies in Álava, Asturias or Teruel. The importance of this fossil record is of international scope, since there are very few examples of amber containing insects of the Aptian-Albian age in the world. Furthermore, this insect record corresponds to a period which is little known but of transcendental importance, since it marks the beginning of the co-evolution of angiosperms and certain groups of insects of high taxonomic rank and highly relevant to current ecosystems.

\section{Stratigraphic sections of the Cretaceous/ Tertiary boundary}

The record of the great biological crisis and global events that occurred around the boundary between the Maastrichtian (Upper Cretaceous) and Danian (Palaeocene) is exceptionally well documented in various Spanish sections (Figure 6). Furthermore, some of the Spanish sections manifest a continuity with other limits associated with extinction events, such as those of the Palaeocene/Eocene and Eocene/Oligocene transitions (Zumaya and Caravaca).

In the Pyrenean domain, there are various deep-sea stratigraphic sequences of appreciable continuity around the CretaceousTertiary boundary. The study of these sequences is favoured by the abundance of fossils, by the fine stratification and by the absence of tectonic or turbiditic alterations. This allows all the physical and biological events to be studied in detail, with the support of the most modern methods in isotopic geochemistry, cyclostratigraphy, magnetostratigraphy and high-resolution biostratigraphy (except calcareous nanofossils). The most representative sections are to be found in the Basque Basin, essentially at Zumaya and Sopelana (Lamolda, 1990; Wiedmann, 1988; Ward et al., 1991) and at Osinaga (Canudo and Molina, 1992).

In the Betic Chains, the sections of Caravaca and Agost (Canudo et al., 1991) and Alamedilla (Linares and Martínez Gallego, 1971), also in marine environments, represent some of the most complete sections at world level pertaining to the Cretaceous/Tertiary boundary.

Other outcrops corresponding to the Cretaceous/Tertiary boundary in the Pyrenees are continental sequences ("Facies Garumn") or shallow marine environments, differentiated fundamentally on the basis of palynological criteria. Detailed magnetostratigraphic and isotopic geochemistry studies have been made, as well as of the biotic events that affected both plants and vertebrates (extinction of dinosaurs) (Galbrun et al., 1993; López-Martínez et al. 1999).

\section{Southern Pyrenean synorogenic basins}

The southern Pyrenean foreland basin is exceptional for the study and knowledge of the relations between the structural evolution of the Alpine orogeny and the sedimentary evolution of its foreland basin (Figure 7). Its reduced dimensions and high degree of exposure lead to the existence in geographically relatively small areas of magnificent outcrops which allow for the study of the sedimentary architecture and depositional facies from fluvial and alluvial systems to others of turbiditic nature, as well as of the relationships between tectonics and sedimentation. For this reason, this basin is being used to train thousands of geologists from around the world. 
From the point of view of the sedimentary architecture, the outcrops of evaporitic facies are especially relevant (Orti et al., 1986), as are those of alluvial and fluvial origin (Puigdefabregas et al., 1989); the fan deltas and deltas with magnificent examples (Anadón et al., 1985 and Crumeyrolle, 1987), the siliciclastic slopes and turbiditic systems (Mutti et al., 1985) with examples from the southern Pyrenean basin being included in most of the specialist books, the carbonates slopes (Barnolas and Teixel, 1994; Payros et al., 1999) and resedimented carbonates facies (Labaume et al., 1987).

Especially outstanding from the point of view of relationships between tectonics and sedimentation also are the progressive unconformities at the Pyrenean and Catalanid margins (Riba, 1976).

\section{Continental Tertiary basins and associated vertebrate fossils in Aragon and Catalonia}

The sequences corresponding to the continental Tertiary in Aragon and Catalonia are among the richest in the world regarding Miocene mammal fossils.

From the palaeontological point of view, the presence of mammal fossils in certain of these basins has been known since the 18th century, and since then several hundred sites have been discovered, mainly with micromammals. The existence of magnificent outcrops with continuous sections containing consecutive superimposed palaeomastological associations served to define a series of biochronological units with chronostratigraphic repercussions, certain of which are widely used in Eurasia (Agustí and Moyà-Solà, 1991).

The continental Miocene is thus subdivided into a series of "divisions" (actually and for the moment, Mammal Ages) which take the names of the basins of Calatayud-Daroca (Ramblian, Daams et al., 1987; Aragonian, Daams et al., 1997), Vallès-Penedès (Vallesian, Crusafont, 1950) and Alfambra-Teruel (Turolian, Crusafont, 1965). In addition to these divisions, the southeast of the Ebro basin has provided excellent biostratigraphic sections belonging to the late Oligocene and its possible boundary with the basal Miocene, whose interval Agustí et al. (1988) proposed should be called the Octogesian. Similarly, deposits containing fossil vertebrates of biostratigraphic interest continue to be represented during the Pliocene in the Alfambra-Teruel basin, where the oldest sediments and fauna of this age led Moissenet et al. (1990) to propose a new division, known as the Alfambrian.

The objective of part of the current research is to convert the biochronological and chronoregistering units represented by the aforementioned Mammal Ages into real chronostratigraphic units of the Eurasian continental Miocene. For this reason, the main stratigraphic sections which are candidates for submission as formal stratotypes at Division level are the subject of modern stratigraphic, geochronological and magnetostratigraphic studies.

Finally, certain Tertiary basins in Aragon house exceptionally well-preserved invertebrate fossil deposits (Peñalver Mollá, 1998).

\section{Olistostromic units of the Betic foreland basin (southern Spain)}

One of the most outstanding characteristics of the Betic foreland basin is the presence of extensive formations of olistostromic nature, which have been known and studied for many years, especially in the valley of the Guadalquivir.

In this region, the oblique collision of the African and European plates, which became accentuated from the upper Palaeogene, caused tectonic piling to the west and northwest, giving rise to the Betic Chains and deforming the Iberian foreland by flexuring. The foreland basin thus produced had its active margin to the south and its passive margin to the north.

In the Guadalquivir valley, clastic sedimentary filling began in the Langhian, with the deposit of olistostromic units extending from the extreme SW of the active edge of the Betic Chain (province of Cadiz) to the extreme NE (province of Alicante), and even to the Balearic Islands. These thick far-reaching olistostromic accumulations were deposited thanks to the disarticulation and dismantling of the orogenic front of the external Betic zones, thus supplying important quantities of Mesozoic, Palaeogene and lower Miocene materials to the basin. Levels of high plasticity abound in these materials, favouring of gravitational slide phenomena.

The interest of the olistostromic units of this area arises from the wide geographical representation and spectacular stratigraphic architecture, with slumps, mud flows, debris flows and abundant blocks or olistolites included, many of which measure kilometres, all being controlled by the advance and dismantling of the Betic front.

For forty years these materials have attracted the interest of numerous authors from various countries; especially outstanding have been the works by Bourgois (1978), in the western third of the basin, Perconig (1960-1962), Foucault (1971) and Roldán (1995) in the central third, and Hoedemaker (1973) and García-Cortés et al. (1991) in the eastern third.

Subsequently, from the upper Serravallian, the basin was filled with turbiditic deposits, which gradually lost predominance to shelf deposits, initially external and later shallow during the upper Messinian-Pliocene (except in the extreme SW of the basin).

\section{Evaporitic Messinian episodes (Mediterranean salinity crisis)}

In the southeast of the Iberian Peninsula, where the Betic Chain has its eastern limit, there are various sedimentary basins which were generated during the Neogene at the western margin of the Mediterranean Sea. They preserve all the elements that have characterised the complex evolution of the terminal Neogene. Following deposition of the marine terrigenous sediments during the Tortonian, marine transgression occurred, allowing important carbonate platforms to develop in these basins, including a great abundance of reefs. Continuing with geological evolution, after the carbonated shelf there was an important drop in sea level that caused sub-aerial exposure with partial erosion of the reefs and a hiatus of sedimentation. This enormous drop in sea level (approximately 1,500 metres) is a unique occurrence and of great importance, since it led to the desiccation of the Mediterranean Sea in the so-called "Messinian salinity crisis", with the deposit of evaporites at the bottom of the basin.

Evaporites have been exhaustively studied within the context of Neogene basins (Martín and Braga, 1994; Clauzon et al., 1996; Michalzik 1996). These outcrops of evaporites constitute an important element throughout the region. The facies predominating in almost all the basins is selenitic twin gypsum of up to several metres in thickness. The gypsums constitute very thick banks (up to $20 \mathrm{~m}$ ) intercalated between detritic levels sometimes containing microfossils.

In some of the basins, the biostratigraphic sequences are considered to be exceptional records of events at the end of the Miocene.

An element of added interest in this context is the shelf of reefs that outcrops at the base of the evaporitic sequences. These Messinian reefs were the last to appear in the geological history of the Mediterranean, and are an outstanding example in the region for their degree of preservation and wide geographic distribution (Martín et al., 1997). 


\section{Vertebrate-bearing deposits of the Spanish Plio-Pleistocene}

The palaeomastological record of the Spanish Quaternary is highly significant in the Eurasian context, since it has unique deposits which have been generated in the three tafosystems with quality palaeontological records: the karstic, the fluvial and the limnic. Apart from the interest of deposits giving testimony to the oldest human presence in Europe, the associations of Plio-Pleistocene vertebrates are taxonomically exceptionally rich. If the different deposits and terrestrial ecosystems represented are combined, the Spanish palaeontological record stands out for its noteworthy continuity over the last two million years.

The fluvial, marsh and lacustrine successions of the Granada basin of Guadix-Baza, mainly those found in the Orce-Venta Micena sector, have provided exceptional records of palaeobiogeographical, biochronological, palaeobiological and archaeological interest. Of these, mention should be made of the succession of micromammals from the Pliocene and the base of the Pleistocene (Agustí et al., 1986), of the diversity and abundance of associations of terrestrial macro- and microvertebrates from the lower Pleistocene, and of the first (indirect) evidence of the earliest human presence in western Eurasia, the latter based on findings of lithic industry in a stratigraphic context of high resolution (Tixier et al., 1995; Martínez Navarro et al., 1997).

The records of the late lower Pleistocene and mid Pleistocene show a practically continuous, and quite exceptional, succession in the karstic complex of the Sierra de Atapuerca (Burgos). The uniqueness of Atapuerca (Figure 8) in the world's Pleistocene register is due to the content of human fossils, with the oldest human fossils known to date in western Europe (Bermúdez de Castro et al., 1997), known as Homo antecessor, and the largest set relating to mid-Pleistocene humans in the world (Arsuaga et al., 1997), related to Homo heidelbergensis.

Other Pleistocene deposits of importance from the palaeontological point of view are those found in the Cueva Victoria (Murcia), where human and primate remains from the lower Pleistocene are known (Gibert et al., 1995; Palmqvist et al., 1996); the Pinilla del Valle deposit (Madrid), with its impressive register of mammals from the Middle Pleistocene and some human teeth (Alférez et al., 1982), attributable to Homo heidelbergensis; and the one at Zafarraya (Granada), a testimony to the last populations of Neanderthals to inhabit the Earth (Hublin et al., 1995).

Finally, because of their palaeontological and archaeological interest, mention should be made of the numerous upper Pleistocene karstic deposits of the Cantabrian Mountains or the foothills of the Central System, as well as those of the system of Quaternary terraces developed in the main Spanish river basins.

\section{Neogene ultrapotassic volcanic associations of southeastern Spain}

This volcanic region, which contains outcrops of calcoalkaline, shoshonitic, basaltic and of some ultrapotassic rocks, is linked to the evolution of the Betic Chains, which experiened a state of subduction of ocean crust, covering the Cretaceous to the Oligocene, followed by processes of continental collision during the Oligocene. Subsequently, between the middle and upper Miocene, the Betic Chains underwent an episode of extensional collapse, during which the volcanic events occurred. These volcanic events took place in a period of between $15 \mathrm{Ma}$ and $6 \mathrm{Ma}$, the ultrapotassic activity being restricted to the last two million years of this period. Subsequently, there were basaltic volcanic manifestations after a period of calm lasting two million years.
The main interest of this volcanic region, from the point of view of the geological heritage, focuses on ultrapotassic volcanism (lamproitic), with which rocks of considerable rarity and interest are associated. The petrological definition of these rocks was first given in the localities of this area, from which they took their names. These ultrapotassic rocks are the jumillites (Ossan, 1906), verites (Ossan, 1889), fortunites (Yarza, 1893) and cancalites (Fúster et al., 1967) (Figure 9).

Being related also to the volcanic processes of this region, the veins type mineralizations of quartz, alunite, gold and sulphides in the mining district of Cabo de Gata and the mineralizations of $\mathrm{Pb}$ $\mathrm{Zn}-\mathrm{Fe}-\mathrm{Mn}-\mathrm{Cu}-\mathrm{Sn}$ and $\mathrm{Ag}$ in the Cartagena-La Unión district are of great interest from a metallogenetic viewpoint. The former are associated with hydrothermal activity related to calcoalkaline volcanism, with hydrothermal alterations in calderas (Rodalquilar), while the latter are hydrothermal mineralizations associated with potassic and shoshonitic calcoalkaline volcanism. These mineralizations have been exploited for more than 2,000 years, until very recently.

\section{Volcanic structures and morphologies of the Canary islands}

On the Canary islands it is possible to study the first states of the formation of an oceanic island since the Albian to the present: interference between the first submarine volcanic episode, represented by haloclastites, breccia and pillow lavas, and the turbiditic sediments reaching the ocean floor from the African continental margin, along with submarine volcanic levels corresponding to more advanced evolutionary states of the islands. Excellent exposures of the basal complexes show the subvolcanic roots of the more recent structures, which are accessible due to the lifting of the islands and the destruction of the relief by erosion or gravitational collapse. Here it is possible to observe dense dike systems and plutonic bodies of different degrees of development, which in certain cases form circular complexes. Likewise, the existence on certain islands of a strong relief and the erosion allow deep cuts to be observed in the volcanic structures, with thick sections of the oldest sub-aerial basaltic structures, and the intruding systems of dikes and necks.

Also found on these islands are exceptional conditions for the observation of different types of major calderas, slide valleys and cone sheets related to calderas, etc. The existence of intense volcanism in very recent times makes it possible to observe the morphologies of centres of emission and volcanic structures of different types (basic and salic) associated with widely varying structures.

Furthermore, the existence of a wide spectrum of igneous materials (volcanic and plutonic) belonging to an oceanic island alkaline association allows them to be completely observed from the point of view of composition (carbonatites, pyroxenites, gabbros, basanites, basalts,...) and structure (philonian and plutonic systems, extrusions, breccia, ignimbritic mantles and tuffs...).

This entire series of characteristics allows the Canary Islands to be considered a privileged natural laboratory for the observation of the volcanism and history of oceanic islands (Fúster, 1981), as well as the different types of constructive or destructive volcanic structures and the lithological, textural and structural characteristics of their materials; all the above is highlighted by easy access, and by the existence of multiple natural parks and protected areas (Figure 10).

Also of great interest are the characteristics of the hydrogeological systems on the different islands, which constitute a complete laboratory for the study of the behaviour of aquifer systems depending on the structure of volcanic features, the morphology and relief of the islands, and their relationship with the climate system.

The collection and use of water is carried out in unique manners; it is possible to find a veritable catalogue of groundwater collection works in very short distances, including horizontal or inclined galleries, boreholes (of up to 800 metres in depth), "Canary Island" wells (opened manually and measuring some $3 \mathrm{~m}$ in diame- 
ter and up to $600 \mathrm{~m}$ in depth, and horizontal galleries at different depths) and normal wells of a smaller depth.

\section{The Iberian Hercynian orogene}

The Iberian Hercynian massif contains valuable tectonic and structural features, two of which are especially outstanding: the transpressive orogene of SW Iberia and the arched orogenous belt of the NW of the Iberian Massif, also known as the "Asturian Knee" or "Ibero-Armorican Arch".

Regarding the transpressive orogene in the SW, it may be stated that the possibility of finding a complete section of an ancient collisional orogene - that is to say, including the two forelands - is very limited. The SW of the Iberian Peninsula is one of the very few places in the world where this may be encountered, and also shows peculiar characteristics related to the strongly transpressive nature (oblique collision) of the conditions under which it was formed. This took place during the so-called Variscan or Hercynian orogeny, in the upper Paleozoic (Ribeiro et al., 1990; Quesada, 1991).

The reconstruction of this sector is critical to an understanding of the vast Paleozoic circum-Atlantic orogenic domain, currently distributed over three continents (Europe, Africa and America), and with a triple joint among the three located precisely in this southern Iberian sector.

The second outstanding feature of the Iberian Hercynian Massif is the spectacular arched structure of the NW Iberian Massif. This section shows an imbricated structure of the first order, of supracortical units arched around a subvertical axis orienting east with centripetal directions of emplacement.

The formation of this Ibero-Armorican arch is interpreted in relation to the collision of a promontory located at the northern margin of Gondwana (Ibero-Aquitano Indentor) with the margin of Laurentia (Quesada, 1991). An intensive imbrication of units would occur in the frontal zones of the promontory, the sector described being the best example of this, while at the margins the lateral ejection of units would prevail, sinistral in the southwest (orogenic segment of the Iberian SW) and dextral in the north-east (French Armorican Massif).

\section{Miocene extension in the Alborán Domain}

The so-called Alborán Domain constitutes the innermost unit of the Arch of Gibraltar, formed as a result of alpine convergence between the Iberian and African plates. This denomination has recently been coined to refer to the so-called Inner Zones of the Betic Chains and the Rif, and to the zone of thinned continental crust that forms the Alborán basin (Balanyá and García Dueñas, 1987).

One of the most characteristic features of this domain is that it refers to an event of extensional deformation of cortical scope (probably also lithospheric) that affected it during the Lower and Middle Miocene, simultaneously with its collision with the external areas of these chains, within the general regime of plate convergence that continues to be active today, albeit attenuated. This extensional event caused a thinning of the previously thickened internal zones, in favour of various batches of subhorizontal detachements and normal faults that affected at least the entire crust (Platt and Vissers, 1989; Aldaya et al., 1991; García Dueñas et al., 1992; Crespo Blanc, 1995; Jabaloy et al., 1995). Subhorizontal ductile structures of extensional detachments predominated in intermediate and lower cortical segments, frequently inverting previously contractive structures; fragile detachments and normal faults with sharp angle predominated in the supracortical domains.

One result of the thinning induced by these structures was the beginning of generation of the Betic reliefs during the upper
Langhian (Braga et al., 1996) and their subsequent development, the exhumation of relatively deep cortical segments (Azañón et al., 1998) and the compartmenting of still-submerged domains, causing the nucleation of what would later become the intramountainous basins, which today are still subjected to uplift (Braga et al., in preparation). The generation of emerged reliefs gave rise to their erosion, which in turn contributed to even further thinning of the crust, favouring the regeneration of the reliefs by the isostatic response to the discharge.

\section{Mercury mineralization in the Almadén region}

The mining district of Almadén contains the world's largest accumulation of mercury resources. Apart from various traces there are seven deposits which altogether imply some $270,000 \mathrm{t}$ of $\mathrm{Hg}$ (more than 7.5 million vials, of which seven are contained in the Almadén deposit). The exceptional nature of the district, and in particular the gigantic deposit at Almadén, is due to the enormous concentration of this metal, whose clarke is very low (of the order $0.5 \mathrm{ppm}$ ), and to the extremely high tonnages accumulated in the area. Furthermore, these deposits are found in a geological context with internal characteristics very different from the rest, thus making them a unique case and leading people to talk of the Almadén metallogenic model.

The district of Almadén is located in the Central Iberian zone of the Iberian Massif. The geotectonic context in which it is located is a stable submerged craton covered with detritic sedimentation. Two detritic sedimentary series may be distinguished: one infra-Ordovician (slates, sandstones and greywackes) and the other of slates and quartzites separated from the former by the Iberian unconformity, representing from the Arenig to the Carboniferous, with some Middle Devonian gaps. In addition to the Armorican quartzite, this series includes other quartzite horizons, with shallow epicontinental platform facies, outstanding among which is the quartzite of lower Silurian age (Llandovery-Wenlock), in which the mineralization is embedded. Another important feature is the existence of basic volcanism, with alkaline affinity (Saupé, 1990), which is manifested in three periods, evolving towards more intermediary types: the Llandeilo (prior to the most important mineralizations, such as Almadén), the Llandovery (simultaneous with them) and the middle Devonian (with intermediate to acidic compositions), in the form of dikes, sills and interstratified extrusions or volcanosedimentary levels. This shows important deuteric alteration (spilitisation). The origin is considered to be mantelic, and clasts of ultrabasic rocks, embedded among the basaltic rocks associated with the deposits, appear frequently. The existence of this local development of deep basic extrusive rocks in a stable cratonic environment suggests an incipient process of rifting and hot spot type volcanism.

There are two main types of mineralizations. The first and more important, the cinnabar mineralization, has fundamentally impregnated the quartzite from the Llandovery age (Figure 11). In the second type of mineralization, the cinnabar appears in veins, forming stockworks in basic volcanic rocks belonging to the three known episodes.

The main mineralization controls are the basic volcanism and the Llandoverian quartzite. The source of such an enormous concentration of mercury is probably a major anomaly at mantelic level.

\section{The Iberian pyrite belt}

This region, located in the SW of the Iberian Peninsula, is, if not the largest, certainly one of the heaviest concentrations of metals and sulphides known, since in a relatively limited surface band (less than $15,000 \mathrm{~km}^{2}$ ) there are almost 100 deposits of massive sulphides and more than 300 of manganese. This is a concentration of more than $1,700 \mathrm{Mt}$ of sulphides, representing an exceptional density of metals. 
Overall, the mineralizations of the Pyrite Belt have been exploited for more than 2,000 years and they imply an accumulation of 14.6 $\mathrm{Mt}$ of $\mathrm{Cu}, 13 \mathrm{Mt}$ of $\mathrm{Pb}, 35 \mathrm{Mt}$ of $\mathrm{Zn}, 46,000 \mathrm{t}$ of $\mathrm{Ag}$ and $880 \mathrm{t}$ of $\mathrm{Au}$ (Leistel et al., 1998).

There are also unique expressions of mineralization, with equally exceptional tonnages, which translate into the existence of various gigantic or world-class deposits, such as those at Río Tinto (Figure 12), Tharsis, La Zarza, Aznalcóllar, Sotiel, etc., in Spain, or Neves Corvo and Aljustrel, in Portugal.

The mineralizations fall into the general VHMS (volcanic hydrothermal massive sulphides) model, but they may be considered as sub-types showing differences from both the geochemical and mineralogical points of view and from their relations with the associated volcanic or volcano-sedimentary structures and sequences. Most of them show evidence of intense modifications induced by subsequent tectonism. Although traditionally included in the Kuroko type or model, their location in a transpressive basin situated at a passive continental margin with dominant detritic sedimentation suggests an independent or specific model, without known modern analogues (Tornos et al, 1999).

The Iberian Pyritic Belt constitutes an especially suitable and favourable environment for the study of volcanogenic deposits, due to the diversity of the characteristics and frames of the structures and zones of associated hydrothermal alteration, and for analysis of deformation in massive sulphide deposits, metallic remobilisation and redistribution, also the genesis of submarine volcanism and its facies, as well as tectonic inversion processes.

\section{Urgonian mineralizations of $\mathrm{Pb}-\mathrm{Zn}$ and Fe in the Basque-Cantabrian basin}

The Basque-Cantabrian basin represents the western end of the Pyrenean Chain. This intraplate basin, formed in the Triassic and related to the beginning of the opening of the North Atlantic, was limited by transforming faults oriented NW-SE, defining a counterclockwise system. Particularly thick beds were accumulated here during the upper Jurassic and the Cretaceous $(15,000 \mathrm{~m})$, a process which was linked to an important extensional subsidence. Three major complexes may be distinguished in the sedimentary record corresponding to this period (Rat, 1959) - the Wealdean, the Urgonian Complex, made up of platform limestones with rudists and by basin marls and lutites, with some siliciclastic intercalations, of Aptian-middle to upper Albian age, and the Supra-Urgonian Complex (upper Albian-Cenomanian).

The Urgonian Complex is an extremely thick (up to 4,000 m) assembly of marine sediments, limited laterally by detritic brackish and fresh water formations in Weald facies, and above by a sandstone complex (Supra-Urgonian Complex), the limestones with rudists being its most characteristic level. Garcia Mondéjar (1996) defines this Urgonian Complex as a set of megacycles or sequences limited by unconformities, containing limestones with Urgonian facies. This cyclic organisation is manifested in alternating terrigenous and carbonated formations limited by surfaces of unconformity, reflecting repeated transitions from regressive to transgressive conditions, with the subsequent sedimentary ruptures controlled by active tectonics. The synchronism characterising the limits of the sequences is to be underlined.

The interest of the Urgonian in the Basque-Cantabrian basin rests on sedimentologic, tectonic, palaeographic and especially metallogenetic aspects.

Regarding these metallogenetic aspects, what is especially noteworthy is the scientific and economic importance of the metallogenetic processes associated with the evolution of the basin during this period, together with the deposits of metallic resources present in the Urgonian sequences. The Basque-Cantabrian basin is located in one of the belts (North Pyrenean belt) of $\mathrm{Zn}-\mathrm{Pb}$ defined by Routhier (1980), which marks a significant and specialised domain of these metals, between Galicia and the Alps. This cortical specialisation is manifested in the basin through the existence of numerous mineralizations of these metals, expressed through diverse typologies, environments and morphologies (replacement, veins, associated with diapirs, Mississippi Valley type, sedimentary exhalative or Sedex...), while showing a close relationship to the Urgonian limestones at the edge of the platform, in which the great majority fit. Among these there are world-class deposits, such as the Reocín deposit, which represents a concentration of more than $4 \mathrm{Mt}$ of $\mathrm{Zn}$ and almost $1 \mathrm{Mt}$ of $\mathrm{Pb}$, all of which have been exploited since the middle of last century.

It is of even greater importance from the economic and historical point of view to mark the Fe mining district of Bilbao, where also with varied morphologies (veins or replacement) and in all cases in dolomitised and silicified Urgonian limestones, there are many mineralizations of siderite, exploitation of which produced more than $300 \mathrm{Mt}$ of $\mathrm{Fe}$ ores since the middle of last century and was the main source of supply for the English iron industry at the end of the 19th century and the beginning of the 20th.

The above types of mineralizations are related to a unique metallogenic process linked to a certain phase of the evolution of the basin and of the basin fluids that channelled through the sinsedimentary faults.

\section{Final considerations}

The list brings a close to the second phase of the methodology established in the Geosites initiative.

The aim in the future is to establish the sites of geological interest (Geosites) representative of each of these frameworks, for which subject matter and/or regional groups of experts will be set up. Certain of these contexts have been defined for the Iberian Peninsula, as a result of which attempts will be made to include our Portuguese colleagues, to the extent to which they wish to collaborate in the initiative.

During this third phase, IGME intends to continue its role as catalyser and coordinator, requesting the participation of the largest possible number of experts in order to guarantee scientific rigour and the highest possible level of representativeness in the process of selecting the Spanish sites of geological interest of greatest relevance at world level.

\section{Acknowledgements}

The IGME working team would like to thank all those research teams who have collaborated in the initiative by responding to the questionnaire distributed and by providing their comments and suggestions. In view of the large number of participants, it is not possible to mention them all, so we shall refer only to the institutions to which they belong:

Department of Environmental Sciences of the University of Gerona, Department of Earth Sciences of the University of Zaragoza, Department of Edaphology and Geology of the University of La Laguna, Department of Stratigraphy of the Madrid Complutense University, Department of Stratigraphy and Palaeontology of the University of Barcelona, Department of Mines Prospecting and Exploitation of the University of Oviedo, Department of Geology of the University of Jaén, Department of Geology of the University of Oviedo, Department of Geology of the University of Valencia, Department of Geology and Ecology of the University of Málaga, Department of Geological Engineering of the Madrid Polytechnic University, Department of Mining, Geological and Cartographical Engineering of the Polytechnic University of Cartagena, Department of Palaeontology of the Madrid Complutense University, Spanish Geological and Mining Institute, Isidro Parga Pondal University Institute of Geology, National Museum of Natural Sciences, Spanish Geological Society and Spanish Society for the Defence of the Geological and Mining Heritage. 


\section{References}

Agustí, J. and Moyà-Solà, S., 1991, Spanish Neogene Mammal successions and its bearing on continental biochronology. Newsletters on Stratigraphy, 25 (2), 91-114.

Agustí, J., Cabrera, L., Anadón, P. and Arbiol, S., 1988, A Late OligoceneEarly Miocene rodent biozonation from the SE Ebro Basin (NE Spain): A potential mammal stage stratotype. Newsletters on Stratigraphy, 18 (2), 81-97.

Agustí, J., Moyà-Solà, S. and Pons-Moyà, J., 1986, Venta Micena (GuadixBaza basin, South-Eastern Spain): Its place in the Plio-Pleistocene Mammal succession in Europe. Geologica Romana, 25, 33-62.

Aldaya, F., Álvarez, F., Galindo Zaldívar, J., Gonzalez Lodeiro, F., Jabaloy, A. and Navarro Vila, F., 1991, The Mal-guide-Alpuj.rride contact (Betic Cordilleras, Spain): a brittle extensional detachment. C.R. Acad. Sci. Paris, 313: 1447-1453.

Alférez, F., Molero, G., Maldonado, E., Bustos, V., Brea, P. and Buitrago, A.M., 1982, Descubrimiento del primer yacimiento Cuaternario (risswürm) de vertebrados con restos humanos en la provincia de Madrid. Coloquios de Paleontología, 37, 15-32.

Anadón, P., Marzo, M., Puigdefabregas, C., 1985, The Eocene Fan-Delta of Montserrat (Southeastern Ebro Basin, Spain), excursion no 3, 6th European Regional Meeting, IAS, Excursion Guidebook, pp.109-146, Lleida.

Arsuaga, J.L., Carretero, J.M., Lorenzo, C., Gracia, A., Martínez, I., Berm dez de Castro, J.M. and Carbonell, E., 1997, Size variation in Middle Pleistocene humans. Science, 277, 1086-1088.

Ayala, F.J., Rodríguez Ortíz, J.M., Del Val, J., Durán, J.J., Prieto, C. and Rubio J., 1986, Mapa del Karst de España. Mapa Escala 1:1.000.000 y Memoria de 68 pp. Instituto Geológico y Minero de España, Madrid.

Azañón, J.M., García Dueñas, V. and Goffé, B., 1998, Exhumation of highpressure metapelites and coeval crustal extension in the Alpuj.rride Complex (Betic Cordillera). Tectonophysics, 285: 231-252.

Bahamonde, J.R., Colmenero, J.R., and Vera, C., 1997, Growth and demise of Upper Carboniferous carbonate platforms in the Eastern Cantabrian Zone, Asturias, NW Spain. Sedimentary Geology. 110. 99-122.

Balanyá, J.C., and García Dueñas, V., 1987, Les directrices structurales du Domaine d'Alborán de part et d'autre du Détroit de Gibraltar. C.R. Acad. Sci. Paris, 304: 929-933.

Barnolas, A., Teixell, A., 1994, Platform sedimentation and collapse in a carbonate-dominated margin of a foreland basin (Jaca basin, Eocene, southern Pyrenees). Geology, 22: 1107-1110.

Bermúdez de Castro, J.M., Arsuaga, J.L., Carbonell, E. Rosas, A., Martínez, I. and Mosquera, M., 1997, A hominid from the lower Pleistocene of Atapuerca, Spain: possible ancestor to neanderthals and modern humans. Science, 276, 1392-1395.

Bertrand, G., 1971, Morphostructures cantabriques: Picos de Europa, Montaña de León et Palencia (Espagne du nord-ouest). Revue Geographique des Pyrénées et du Sudouest, 42, 1: 49-70.

Birot, P., and Solé, I., 1954, Recherches morphologiques dans le Nord-Ouest de la península ibérique. mém et doc. du cnrs, 4: 9-61.

Borja, F., Zazo, C., Dabrio, C.J., Díaz del Olmo, F., Goy, J.L. and Lario, J., 1999, Holocene aeolian phases and human settlements along the Atlantic coast of southerm Spain. The Holocene, 9: 333-339.

Bourgois, J., 1978, La transversale de Ronda. Données géologiques pour un modèle d'évolution à l'arc de Gibraltar. Thèses Doct. Univ. Besançon. 30. $445 \mathrm{pp}$.

Braga, J.C., Jiménez, A.P., Martín, J.M., and Rivas, P., 1996, Coral-oyster reefs (Middle-Miocene), Murchas, Granada, Southern Spain. in: Models for carbonate stratigraphy from Miocene reef complexes of Mediterranean regions (E. K. Franseen, M. Esteban, B. Ward and J. M. Rouchy, eds.), Soc. Econ. Paleont. Mineral. Concepts in Sedimentology and Paleontology Series, 5: 131-139.

Braga, J.C., Martín, J.M., and Quesada, C., (in prep.), Patterns and rates of uplift in the Betic Cordillera. In Landscape Development, Southern Spain (A.E. Mather and M. Stokes, Eds). Geomorphology (Special Issue).

Calaforra, J.M., 1996, Contribución al conocimiento de la karstología de yesos. Tesis Doctoral, Universidad de Granada.

Canudo, J.I. and Molina, E., 1992, Bioestratigrafía y evolución de los foraminíferos del límite Cretácico/terciario en Osinaga (Pirineo de Navarra). Actas III Congreso Geológico de España, 2, 54-62.

Canudo, J.I., Keller, G. and Molina, E., 1991, Cretaceous/Tertiary boundary pattern and faunal turnover at Agost and Caravaca, SE Spain. Marine Micropaleontology, 17, 319-341.

Casanovas, M.L., Ezquerra, R., Fernández, A., Pérez-Lorente, F., Santafé, J.V., and Torcida, F., 1992, Tracks of herd of webbed ornithopods and other footprints found in the same site (Igea, La Rioja, Spain). Revue de
Paléobiologie. Second Georges Cuvier Symposium. Montbeliard (7 spec) $37-44$.

Clauzon, G., Suc, J.P., Gautier, F., Berger, A. and Lautre, M.F., 1996, Alternate interpretation of the Messinian salinity crisis: Controversy resolved?,. Geology, 24, 4, 363-366.

Crespo Blanc, A., 1995, Interference pattern of extensional fault systems: a case study of the Miocene rifting of the Alborán basement (North of Sierra Nevada, Betic Chain). Jour. Struct. Geol., 17: 1559-1569.

Crumeyrolle, P., 1987, Stratigraphie physique et sédimentologie des systèmes de dépot de la séquence de Santa Liestra (Eocène sud-pyrénéen, Pyrénées Aragonaises, Espagne). Thèse, Univ. de Bordeaux III, 216 p.

Crusafont, M., 1950, El sistema miocénico en la depresión española del Vallès-Penedès. Proceedings 18th International Geological Congress, London 1948, 11, 33-42.

Crusafont, M., 1965, Observations à un travail de M. Freudenthal et P. Y. Sondaar sur des nouveaux gisements à Hipparion d'Espagne. Proc. Kon. Ned. Akad. Wetensch., [B], 68 (3), 121-126.

Daams, R., Freudenthal, M. and Alvarez Sierra, M.A., 1987, Ramblian, a new Stage for continental deposits of Early Miocene age. Geologie en Mijnbouw, 65, 297-308.

Daams, R., Freudenthal, M. and Van de Weerd, A., 1977, Aragonian, a new stage for continental deposits of Miocene age. Newsletters on Stratigraphy, $6(1), 42-55$.

Durán, J.J., 1996, Los sistemas kársticos de la provincia de Málaga y su evolución: contribución al conocimiento paleoclim.tico del Cuaternario en el mediterráneo occidental. Tesis Doctoral, Universidad Complutense de Madrid, 409 pp. Madrid.

Elízaga, E., Gallego, E., et García-Cortés, A., 1994, Inventaire national des sites d'interêt géologique en Espagne: méthodologie et déroulement. Mem. Soc. Géol. France. 164. pp 103-110.

Foucault, A., 1971, Etude géologique des environs des sources du Guadalquivir (Provinces de Jaén et de Grenade, Espagne meridionale). Thèses Univ. ParÌs VI. 663 pp.

Fuster, J.M., 1981, Evolución geológica del Archipiélago Canario. R. Acad. Cienc. Ex. Fis. Nat., Discurso, Madrid, 9-50.

Fuster, J.M., Gastesi, P., Sagredo, J. and Fermoso, M.L., 1967, Las rocas lamproíticas del SE de España. Est. Geol., 23, 35-69.

Galbrun, B., Feist, M., Colombo, F., Rocchia, R., and Tambareau, Y., 1993, Magnetostratigraphy and biostratigraphy of Cretaceous-Tertiary continental deposits, Ager basin, province of Lerida, Spain. Palaeogeography, Palaeoclimatology, Palaeoecology, 102, 41-52.

García Dueñas, V., Balanyá, J.C. and Martínez Martínez, J.M., 1992, Miocene extensional detachments in the outcropping basement of the northern Alborán Basin and their tectonic implications. Geo-Marine lett., 12: 88-95.

García Mondéjar, J., Agirrezabala, I., Aranburu, A., Fernández- Mendiola, P., Gómez Pérez., López-Horgue, M., Rosales, I., 1996, Aptian-Albian Tectonic Pattern of the Basque-Cantabrian Basin (northern Spain).- Geological Journal. vol. 31, 13-45.

García-Alcalde, J.L., 1996, El Devónico del Dominio Astur-Leonés en la Zona Cant.brica ( $N$ de España). Revista Española de Paleontología, ${ }^{\circ}$ extraordinario 1996, 58-71.

García-Alcalde, J.L., Montesinos, J.R., Truyols-Massoni, M., García-López, S., Arbizu, M.A. and Soto, F., 1990, The Palentine Domain (Palentian Zone). In Dallmeyer, R.D. and Martínez García, E. (eds.), Pre-Mesozoic Geology of Iberia. Springer-Verlag, Berlin-Heidelberg, 20-23.

García-Cortés, A., Quintero, I. and Mansilla, H., 1991, Puesta de manifiesto de la Unidad Olistostrómica del Mioceno medio, en el sector oriental de las Cordilleras Béticas. Bol. Geol. y Min. 102-4. pp 524-535.

Gibert, J., Leakey, M., Arribas, A., Ribot, F., Martínez, B. and Gibert, L., 1995, Presence of the Cercopithecid genus Theropithecus in Cueva Victoria (Murcia, Spain). Journal of Human Evolution, 28, 487-493.

Goy, J.L., Zazo, C., Hillaire-Marcel, C., Causse, C., 1986, Stratigraphie et chronologie (U/Th) du Tyrrhénien de SE de l'Espagne. Zeitschrift für Geomorphologye, 62, 71-82.

Gutierrez, F., 1996, Gypsum karstification induced subsidence: Effects on alluvial systems and derived geohazards, Calatayud Graben, Iberian Range, Spain. Geomorphology, 16, 277-293.

Gutiérrez-Marco, J.C., Rábano, I., San José, M.A., Herranz, P. and Sarmiento, G.N.,1995, Oretanian and Dobrotivian stages vs. "LlanvirnLlandeilo" Series in the Ordovician of the Iberian Peninsula. In Cooper, J.D., Droser, M.L. and Finney, S.C. (eds.), Ordovician Odyssey. Pacific Section Society for Sedimentary Geology, book 77, 55-59.

Gutiérrez-Marco, J.C., Robardet, M. and Piçarra, J.M., 1998, Silurian stratigraphy and paleogeography of the Iberian Peninsula (Spain and Portugal). Temas Geológico-Mineros IGME, 23, 13-44. 
Heredia, N., Rodríguez-Fernández, L.R. and Wagner, R.H., 1990, Carboniferous of the Palentine Zone. in Pre-Mesozoic Geology of Iberia. (Dallmeyer, R.D., y Martinez-Garcia, E., eds.). Springer-Verlag, 33-38.

Hoedemaker, P.S., 1973, Olistostromes and other delapsional deposits, and their occurence in the region of Moratalla (Province of Murcia, Spain). Scripta Geol. 19. 207 pp. Amsterdam .

Hublin, J.J., Barroso-Ruiz, C., Medina-Lara, P., Fontugne, M. and Reyss, J.L., 1995, The Mousterian site of Zafarraya (Andalucia, Spain): dating and implications on the palaeolithic peopling processes of Western Europe. Comptes Rendus de l'Académie des Sciences de Paris, 321, série II.

Jabaloy, A., Galindo Zaldívar, F., González Lodeiro, F. and Aldaya, F., 1995 , Main features of the deep structure of the central Betic Cordillera (SE Spain) from the ESCI-Béticas deep seismic refection profiles. Rev. Soc. Geol. España, 8: 461-476.

Knight, J., 1983, The stratigraphy of the Stephanian rocks of the Sabero Coaldfield, León (NW Spain) and an investigation of the fossil flora. Part I. The Stratigraphy and general geology of the Sabero Coalfield. Palaeontographica, Abt. B, 187, 1-88.

Labaume, P., Mutti, E. and Seguret, M., 1987, Megaturbidites: a depositional model from the Eocene of the SW-Pyrenean foreland basin, Spain. geo.marine letters, 7: 91-101.

Lamolda, M.A., 1990, The Cretaceous-Tertiary boundary crisis at Zumaya (northern Spain). Micropaleontological data. in Walliser, O. (ed.), Global Bioevents, Extinction Events in Earth History.8, 393-399.

Leistel, J., Marcoux, E., Thiéblemont, D., Quesada, C., Sánchez, A., Almodóvar, G., Pascual, E. and Sáez, R., 1998, The volcanic-hosted massive sulphide deposits of the Iberian Pyrite Belt. Mineralium Deposita 33: $2-30$.

Linares, D. and Martínez Gallego, J., 1971, Observaciones sobre el tránsito Cretáceo-Paleógeno en el sector de Alamedilla (Provincia de Granada) Cuadernos de Geología, Granada, 2, 137-146.

Liñán, E., Perejón, A. and Sdzuy, K., 1993, The Lower-Middle Cambrian stages and stratotypes from the Iberian Peninsula: a revision. Geological Magazine, 113, 817-833.

López-Martínez, N., Fernández-Marrón, M.T., and Valle, M.F., 1999, The succession of vertebrates and plants across the Cretaceous-Tertiary boundary in the Tremp Formation, Ager valley (South-central Pyrenees, Spain). Geobios, 32 (4), 617-627.

Martín, J.M., and Braga, J.C., 1994, Messinian events in the Sorbas Basin in southeastern Spain and their implications in the recent history of the Mediterranean. Sedimentary Geology, 90, 257-268.

Martín, J.M., Braga, J.C., and Riding, R., 1997, Late Miocene Halimeda alga-microbial segment reefs in the marginal Mediterranean Sorbas Basin, Spain. Sedimentology, 44, 441-456.

Martín-Algarra, A., Ruiz Ortiz, P.A. and Vera, J.A., 1992, Factors controlling cretaceous turbidite deposition in the Betic Cordillera. Rev. Soc. Geol. España, 5, 1-2, 53-80.

Martínez-Diaz, C., Granados, L.F., Leyva, F., Laveine, J.P., Solovieva, M.N., Reitlinger, E.A., Gervilla, M., Lobo-Ziak, S., Brousmische, C., Candilier, A.M., P., Pendás, F., and Horvath, V., 1983, Aportaciones a la cronoestratigrafía del Carbonífero medio de Asturias y nuevos datos para un intento de correlación de las escalas marinas y continentales. Compte Rendu X Congrés International de Stratigraphie et de Gèologie du Carbonifére. vol. i, 269-280.

Martínez-Navarro, B., Turq, A., Agustí, J. and Oms, O., 1997, Fuente Nueva3 (Orce, Granada, Spain) and the first human occupation of Europe. Journal of Human Evolution, 33, 611-620.

Martín-Serrano, A., 1988, Sobre la posición de la raña en el contexto morfodinámico de la Meseta. Planteamientos antiguos y tendencias actuales. Bol. Geol. Min. España, 99: 855-870.

Martín-Serrano, A., 1991, La definición y el encajamiento de la red fluvial actual sobre el Macizo Hespérico en el marco de su geodinámica alpina. Rev. Soc. Geol. España, 4 (3-4): 337-351.

Michalzik, D., 1996, Lithofacies, diagenetic spectra and sedimentary cycles of Messinian (Late Miocene) evaporites in SE Spain. Sedimentary Geology, 106, 203-222.

Moissenet, E., Lindsay, E.H., Mein, P., Opdyke, N. and Pérez-González, A., 1990, The Alfambrian: A new continental stage for the pliocene formations of Teruel Basin. Biostratigraphy, magnetostratigraphy, referenced sections. IX R.C.N.S. Congress, Barcelona, 245-247.

Molina, E., Blanco, J.A., Pellitero, E., and Cantano, M., 1987, Weathering processes and morphological evolution of the Spanish Hercynian massif, in International Geomorphology, 1986 Part. II. Gardiner, V. Ed. 957-977. John Willey and Sons.

Mutti, E., Remacha, E., Sgavetti, M., Rosell, J., Valloni, R., and Zamorano, M., 1985, Stratigraphy and Facies Characteristics of the Eocene Hecho
Group Turbidite Systems, South-Central Pyrenees. Excursion Guidebook of I.A.S. 6th. Europen Regional Meeting. Excursion no. 12, pp. 519-576.

Orti, F., Salvany, J.M., Rosell, L., Pueyo, J.J. and Ingles, M., 1986, Evaporitas antiguas (Navarra) y actuales (Los Monegros) de la Cuenca del Ebro, Excursión n ${ }^{\circ}$ 2, XI Congreso Español de Sedimentología, Guias de las excursiones, p. 2.1-2.40, Barcelona.

Ossan, A., 1889, Beitrage zur kentniss der eriptivegestcine des Cabo de Gata I. Zeist. Deusts. Geol. Gerellnchaft, 4112, 297-311.

Ossan, A., 1906, Uber einige alkaligesteine aus Spanien. Rosenbasch Fests., 263-310.

Palmqvist, P., Pérez-Claros, J.A., Gibert, J. and Santamaría, J.J., 1996, Comparative morphometric study of a human phalanx from the Lower Pleistocene site at Cueva Victoria (Murcia, Spain), by means of Fourier analysis, shape coordinates of landmarks, principal and relative warps. Journal of Archaeological Science, 23, 95-107.

Payros, A., Pujalte, V. and Orue-Etxebarria, X., 1999, The South Pyrenean Eocene carbonate megabreccias revisited: new interpretation based on evidence from the Pamplona Basin. Sedimentary Geology, 125, 165-194.

Peñalver Mollá, E., 1998, Estudio tafonómico y paleoecológico de los insectos del Mioceno de Rubielos de Mora (Teruel). Instituto de Estudios Turolenses, Teruel, 179 págs.

Perconig, E., , 1960-62, Sur la constitution géologique de l'Andalousie occidentale, en particulier du bassin du Guadalquivir (Espagne mérdionale) in livre à la mémoire du Prof. P. Fallot. Mem. H-serie S.G.F. 1. pp 229-256.

Platt, J.P. and Vissers, R.M.L., 1989, Extensional collapse of thickened continental lithosphere: A working hypothesis for the Albor.n Sea and Gibraltar Arc Geology, 17: 540-543.

Puigdefabregas, C., Collinson, J., Cuevas, J.L., Dreyer, T., Marzo, M., Mellede, D., Mercade, I., Muñoz, J.A., Nijman, W. and Verges, J., 1989 Alluvial Deposits of the successive Foreland Basin stages and their relation to the Pyrenean thrust sequences. Guidebook series of the 4th International Conference on Fluvial Sedimentology. Publ. Servei Geològic de Catalunya: $171 \mathrm{p}$.

Quesada, C., 1991, Geological constraints on the Paleozoic tectonic evolution of tectonostratigraphic terranes in the Iberian Massif. Tectonophysics, 185: 225-245.

Rábano, I., Robardet, M. and Gutiérrez-Marco, J.C., 1999, Tthe Valle syncline: an exceptional geological area in the Natural park of the Sierra Norte of Seville (Andalusia, Southern Spain). in Barettino, D., Vallejo, M. and Gallego, E., eds., Towards the Balanced Management and Conservation of the Geological Heritage in the New Millenium. Sociedad Geológica de España, 262-265.

Rat, P., 1958, Lles pays crétacés Basco-Cantabriques, Espagne. Publ. Univ. Dijon 18. pp.1-525.

Riba, O., 1976, Syntectonic unconformities of the Alto Cardener, Spanish Pyrenees: a genetic interpretation. Sedimentary Geology, 15: 213-233.

Ribeiro, A., Quesada, C. and Dallmeyer, R.D., 1990, Geodynamic evolution of the Iberian Massif. in Pre-Mesozoic Geology of Iberia, R.D., Dallmeyer and E. MartÌnez García (eds.), Springer-Verlag, pp. 399-409.

Roldán, F.J., 1995, Evolución neógena de la Cuenca del Guadalquivir. Tesis Univ. Granada. 260 pp.

Routhier, P., 1980, Où sont les métaux pour l' avenir? Les provinces métalliques. Essai de Métallogénie globale. Mémoire b.r.g.m. nº 105.

Ruiz-Ortiz, P.A., Molina, J.M., and Vera, J.A., 1985, Coral-ooid-oncoid facies in a shallowing-upward secuence of the Middle Jurassic (External Subbetic, Southern Spain). 6 th European Reg. Meet, I.A.S., Lleida, Abs. 403-406

Saupé, F., 1990, Geology of the Almadén Mercury Deposit, Province of Ciudad Real, Spain. Economic Geology. Vol.85, 1990, pp. 482-510.

Tixier, J., Roe, D., Turq, A., Gibert, J., Martínez, B., Arribas, A., Gibert, L., Maillo, A. and Iglesias, A., 1995, Presence d'industries lithiques dans le pléistocène inférieur de la région d'Orce (Grenade, Espagne): état de la question. Comptes Rendus de l'Académie des Sciences de Paris, 321, série II a, 71-78.

Tornos, F., Locutura, J. and Martins, I., 1999, The Iberian Pyrite Belt. Joint SGA-IAGOD International Meeting. Field Trip B4. IGME-IGM. 49 pp.

Vera, J.A., 1988, Evolución de los sistemas de depósito en el margen ibérico de la Cordillera Bética. Rev. Soc. Geol. España, 1, 3-4, 373-391.

Villa, E., 1995, Fusulináceos carboníferos del este de Asturias (N de España). Biostratigraphie du Paléozoïque, 13, 261 pp.

Wagner, R.H., Fernández-García, I.G., and Eagar, R.M.C., 1983, Geology and palaeontology of the Guardo Coalfield (NE León-NW Palencia), Cantabrian Mts. Inst. Geol. Min. Esp., Madrid, 109 pp., 49 pls.

Ward, P.D., Kennedy, W. J., Mcleod, K.G. and Mount, J.F., 199, Ammonite and inoceramid bivalve extinction patterns in Cretaceous/Tertiary bound- 
ary sections of the Biscay region (southwestern France, northern Spain). Geology, 19, 1181-1184.

Wiedmann, J., 1988, The Basque coastal sections of the K/T boundary. A key to understanding "mass extinction" in the fossil record. Revista Española de Paleontología, $\mathrm{n}^{\circ}$ extraordinario 1988, 127-140.

Wimbledon, W.A.P., 1998, An european geosite inventory: GEOSITE — an International Union of Geological sciences iniciative to conserve our geological heritage. Comunicaciones de la IV Reunión Nacional de Patrimonio Geológico. Miraflores de la Sierra (Madrid) pp 15-18.

Wimbledon, W.A.P. 1996. GEOSITES- a new IUGS initiative to compile a global comparative site inventory, and aid to international and national conservation activity. Episodes, 19: 87-88.
Yarza, A., de 1893, Roca eruptiva de Fortuna (Provincia de Murcia). Bol. Com. Mapa Geol. Esp., 20, 349-353.

Zazo, C. and Goy, J.L., 1994, Litoral español. In: M. Gutierrez (ed.) Geomorfología de España, 437-469. rueda.

Zazo, D., Dabrio, C.J., Borja, F., Goy, J.L., Lezine, A.M., Lario, J., Polo, M.D., Hoyos, M. and Boersma, J.R., 1999, Pleistocene and Holocene aeolian facies on the Huelva coast (Southern Spain): climatic and neotectonic implications. Geologie Mijnbouw, 77: 209-224.

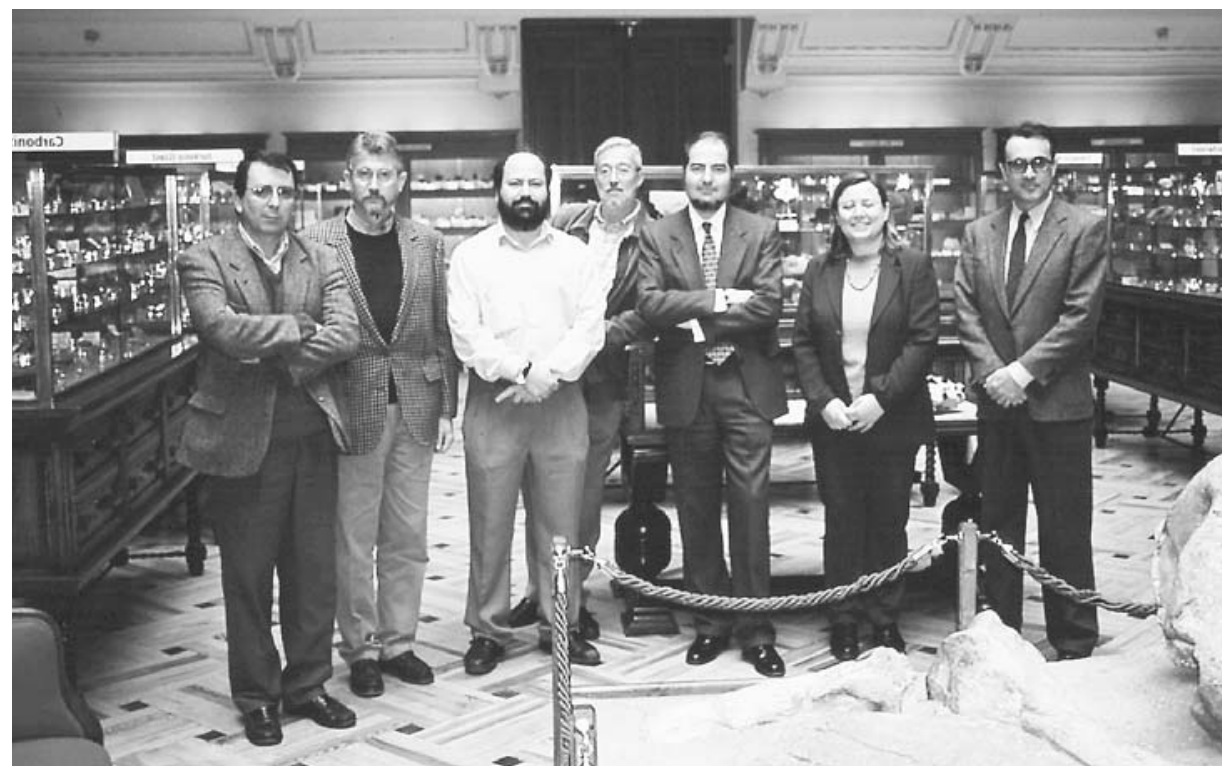

Left to right: Dr. Fernández-Gianotti, Dr. Rábano, Dr. García-Cortés, Mr. Quesada, Dr. Durán, Dr. Bellido and Mr. Locutura.

Ángel García-Cortés is Doctor in Mining Engineering (Geological and Geophysical branch) at the Madrid School of Mines. He joined the Spanish Geological Survey (IGME) in 1981, where he has been involved in a wide number of projects dealing with geological mapping, geoenvironment and coal resources. At present he is Director of Geology and Geophysics. Since 1988 he is Professor in the Madrid School of Mines, teaching on Stratigraphy and Paleontology. His research interest is focused on Biostratigraphy and Geological Heritage. He is Vice-President of the Spanish Geological Society and National Correspondent in Spain of ProGEO (European Association for the Conservation of the Geological Heritage)

Juan Locutura is Mining Engineer at Madrid School of Mines (1971), in the branch of Mining Exploration and Geology. Senior engineer in the Mineral Resources Division IGME. At present, Head of Metallogeny and Geochemistry Department at IGME. He has been involved in a wide number of projects in the fields of mining exploration, geochemical and metallogenic mapping and modelling, and mineral economics. His present research interest is in the field of geochemical mapping with environmental purposes, in resources inventories and metallogenic maps.
Isabel Rábano is Ph.D. in Palaeontology. In 1990 she joined the Spanish Research Council, and since 1993 is the Director of the Museum of the Spanish Geological Survey. Her research interest is focused on the systematics, biostratigraphy and faunal dynamics of Ordovician-Silurian trilobites from SW Europe, North Africa and South America, as well as on Spanish geological and palaeontological heritage. She is Vice president of the Society for the Defence of the Spanish Geological and Mining Heritage and participates in working groups of several IUGS projects.

Félix Bellido received his PhD in Igneous Petrology from the Complutense University of Madrid in 1979. He was Associate Professor in the Department of Petrology and Geochemistry of the same university from 1976 since 1981. Between 1981 and 1983 he was holder of a post doctoral scholarship in the Museum of Natural Sciences of Madrid. He worked as Senior Geologist from 1983 until 1988 in GEOPRIN S.A., a consultant company of Geology and Mining. Since 1988 he has worked at IGME in geological mapping and research projects focused on igneous and metamorphic terrains of Spain. 


\begin{abstract}
Jorge Fernández-Gianotti received his Doctor degree in Geology from the University of Buenos Aires (Argentina) in 1977. After a wide professional career in mining exploration, from uranium to base metals, with the Spanish Nuclear Energy Agency (JEN) and Exxon Minerals Inc., he joined de Geological Survey of Spain in 1987, where he developed activities related mainly with geological mapping and basic research for radioactive waste geological repositories. At present his scientific activities are focused on the geology of the Mesozoic and Tertiary terrains of the External Betic Cordillera in southern Spain. Since 1996 he is in charge of the secretariat of the Spanish Committee for the IUGS (Comision Nacional de Geología).
\end{abstract}

Antonio Barnolas is Senior Geologist in the Spanish Geological Survey and, at present, Head of of the Department of Geological Studies. He has a wide experience in stratigraphy, geological mapping and marine geology. He is Member of the Spanish Committee for the International Geological Correlation Programme.

Juan-José Durán, Doctor in Geology and Research Geologist with the Spanish Geological Survey. He is Head of Hydrogeological $R+D$ Department. His current research interest includes Karst Geology, Groundwater and Geological Heritage. He is Associate Professor in the Department of Agricultural Chemistry, Geology and Geochemistry of Autonomous University, Madrid. He is Secretary of the Spanish Group of 448 IGCP Project on Karst Geology and its relevant ecosystem.

\begin{abstract}
Ángel Martín-Serrano is a research geologist at the geological mapping area of the Spanish Geological Survey, with a Doctor degree from the Complutense University of Madrid (Spain). He has 26 years of experience on research projects related with Cenozoic continental terrains. He is author of numerous geological and geomorphological maps. At present he is in charge of the Geomorphological Map of Spain program. His research experience is mainly on geomorphology of ancient massifs and Cenozoic. He participated in more than 50 projects related to the Iberian Meseta. He has also worked in the Antarctic Peninsula and in the Andean Cordillera.
\end{abstract}

Cecilio Quesada is Project Leader at the Spanish Geological Survey. He has been involved in mapping and regional geological projects in the southwest Iberian Variscan orogen since 1976. His research interests concentrate on structural geology and tectonics of basement terranes. He has actively collaborated in five IGCP projects and he is currently the leader of the Spanish working group in IGCP project no. 453.

\section{Hutchison 'Young Scientist' Fund}

William Watt Hutchison, "Hutch" to his many friends around the world, was a Scots-born Canadian geologist who served Canada and the IUGS in myriad dynamic and creative ways. Most notably, he served as the IUGS Secretary General (1976-1980) at a pivotal time in its history, and as IUGS President (1984-1987). The same boundless energy, enthusiasm, skill in communications, and ability to foster teamwork that characterized his work with the IUGS also carried him to preeminent scientific administrative positions in the Canadian Government, where he served as Director General of the Geological Survey of Canada and as Assistant Deputy Minister of Earth Sciences. His distinguished career was terminated in 1987 by his untimely death at the age of 52, following a painful struggle with cancer.

One of Hutch's last wishes was to establish under IUGS auspices a memorial foundation intended to promote the professional growth of deserving, meritorious young scientists from around the world by supporting their participation in important IUGS-sponsored conferences.

The Hutchison "Young Scientist Foundation" is a worthy cause that honors a fine, caring man and a distinguished, public-spirited scientist and administrator. The foundation also celebrates and promotes those things that gave Hutch the most professional satisfaction: geology, international scientific collaboration, and stimulating young minds.

The IUGS welcomes contributions to the Hutchison "Young Scientist Foundation." Please send donations to:

$$
\begin{aligned}
& \text { Dr. John A. Reinemund } \\
& \text { P.O. Box 890 } \\
& \text { Leesburg, VA } 20178 \text { USA } \\
& \text { Fax: +1 } 7037774463 \\
& \text { Tel: +1 } 7037771491
\end{aligned}
$$

Checks in US dollars or Visa/Mastercard (please include account number and expiration date) are preferred in order to avoid the high cost of currency conversions. Residents of the U.S.A. are reminded that charitable gifts of this nature are tax deductible. 